\title{
Rationales and Designs to Implement an Institutional Big Bang in the Governance of Global Finance
}

\author{
Emilios Avgouleas*
}

TABLE OF CONTENTS

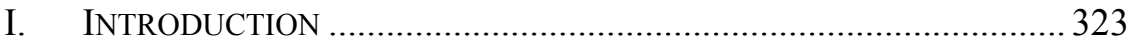

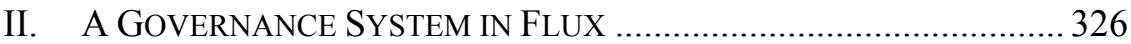

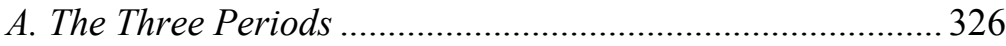

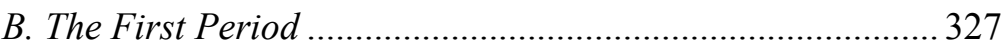

C. Intermediate Phase: A 'New International

Financial Architecture' (1998-2008) ...................................331

1. NIFA Overview and Rationales .................................... 331

2. The Evolution of Standard-Setting Bodies and Financial Standards During NIFA .......................... 334

3. The Role of the G-20 During NIFA ............................... 335

4. The Evolution of the IMF's Role ………………........... 336

5. Financial Stability Forum: International

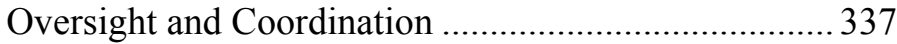

6. BCBS Develops a Risk Sensitive Capital Framework .. 339

7. Implementation-Monitoring and the FSAP Surveys .. 342

8. A Critique of NIFA …............................................... 344

D. The Emerging Architecture …............................................ 344

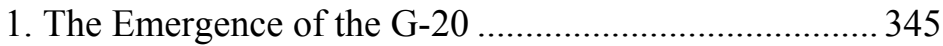

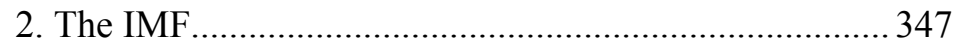

3. From the FSF to the FSB............................................ 347

\footnotetext{
* Professor of International Banking Law and Finance, University of Edinburgh. This Article constitutes the expanded version of author's contribution to the Fourth Adolf Berle Symposium, Seattle University-UCL, June 12, 2012. A small part of this paper draws on EMILIOS AVGOULEAS, Governance of Global Financial Markets-The LaW, the Economics, the Politics (2012). Copyright (C) 2011 Cambridge University Press. The few partly reproduced sections are printed with permission from Cambridge University Press. Because this Article was substantially written and completed before July 31,2012, it does not take into account regulatory reforms that were floated and implemented after that date. Thus, it does not discuss the very important governance reforms pertaining to the European Banking Union and the assumption of responsibility for the supervision of the Eurozone banks by the European Central Bank.
} 
4. The Supervisory Colleges ................................................ 350

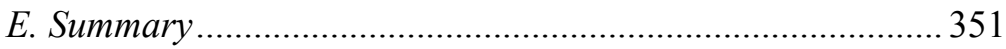

III. CAN SOFT-LAW FInANCIAL GOVERnANCE MEET THE

CHALLENGES? LESSONS FROM THE GFC ….............................. 352

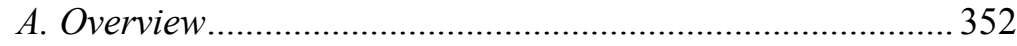

B. Shortcomings in Regulatory Coordination.......................... 354

C. All Is Not Well with Private Sector Input ............................. 357

D. Monitoring and Enforcement of International

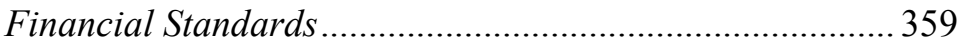

E. The Issue of Legitimacy ........................................................360

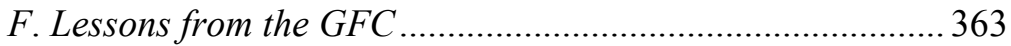

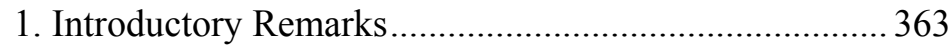

2. The Flaws of the Basel Capital Framework ................... 363

3. Supervisory Failures, Cross-Border

Crisis Management and Resolution "Too-Big-

to-Fail" Institutions......................................................... 366

a. Supervision of Cross-Border

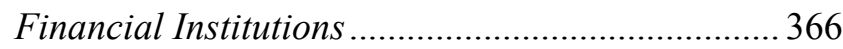

b. Resolution of Cross-Border

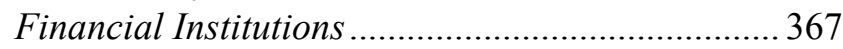

IV. The State OF REFORM WITH RESPECT to BANK

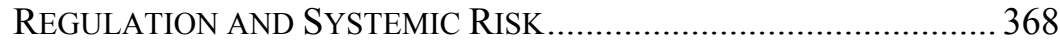

A. Summary of Reforms in the United States and the European

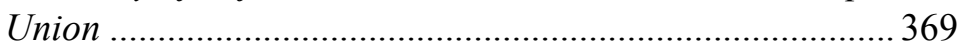

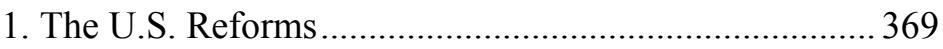

2. Reform in the European Union ...................................... 370

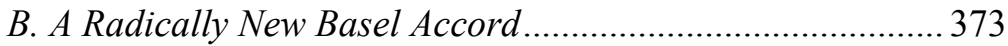

1. The Shift to Macro-prudential Regulation .................... 373

2. New Capital and Liquidity Regulations ....................... 375

V. AN InSTITUTIONAL BIG BANG FOR GLOBAL FINANCE.................... 377

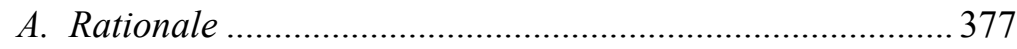

B. The Proposed Governance Model ...................................... 380

1. General Principles: The Importance of

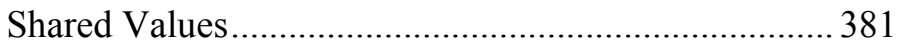

2. The Macro-prudential Supervisor ................................. 384

3. The Micro-prudential Supervisor .................................. 385

4. Global Financial Policy, Regulation, and

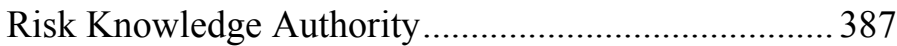

5. A Global Resolution Authority ……………................ 388

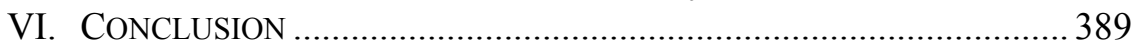




\section{INTRODUCTION}

The colossal challenges facing international finance pertain to both its governance system and its dual utility and speculative functions, which have become ever more intertwined with the advent of financial innovation. In the aftermath of the Global Financial Crisis (GFC), a number of significant reforms are under way to address the second issue, including additional capital and liquidity requirements for banks, measures to battle interconnectedness in the financial sector, new resolution regimes that would allow banks to fail more easily, and stricter frameworks for bank supervision and monitoring of systemic risk. Yet limited progress has been made with respect to governance structures, which, thus, will be the main focus of present analysis. In this Article, I provide an outline of a proposal for a new model of governance for global financial markets to address most of the above challenges in a way that would be more effective than the preexisting regime or the architecture emerging as a result of the GFC.

It is generally accepted that the global financial governance system is premised on four central pillars, which incorporate a diverse "legal" and organizational universe of rules and actors. The first pillar comprises international treaties, on which the most important international financial institutions (IFIs), such as the International Monetary Fund (IMF), the regional development banks, and the World Bank, have been founded. The second pillar encompasses state-to-state contact and coordination groups, such as the Group of Seven most developed countries (G-7) and the Group of Twenty most developed countries (G-20). The third pillar is based on "informal," consensus-based (soft-law) standards and structures (also known as Transnational Regulatory Networks (TRNs)), like the Basel Committee, the International Organization of Securities Commissions (IOSCO), and other soft-law bodies led by the G-20 and the Financial Stability Board (FSB). TRNs encompass regulatory agencies and central banks rather than governments. The private sector is either directly represented or has direct information (and, often, significant policy input). The fourth pillar is the public-private sector partnership, which constituted, in the past, the cornerstone of the rulemaking process of this framework but is now much less prominent, although global financial services industry bodies and other organizations are still key know-how providers to TRN standard-setters.

The existing complex web of TRNs, aided by IFIs and the universe of private-sector bodies actively involved in global financial governance, tend to cooperate in three governance spheres. First, TRNs and privatesector bodies are strongly involved with the development of best practice 
standards, normally called International Financial Standards (IFSs). ${ }^{1}$ These are generally accepted principles, practices (acting as "default rules"), and guidelines, ranging from accounting standards to disclosure rules for securities issuers and capital adequacy requirements of banks. Most of the IFSs are incorporated into TRN member and nonmember jurisdictions through national implementation. On the other hand, both TRNs and IFIs are involved in monitoring compliance with the IFSs, either through TRN peer review procedures or through the IMF and the World Bank's Financial Sector Assessment Program (FSAP) and reports on the observance of standards and codes (ROSCs). Finally, enforcement of cooperation is premised on bilateral and multilateral (quasi-binding) memoranda of understanding (MOUs).

Most of the soft-law standards issued by the TRNs (and the IFIs) eventually find their way into national legislation or the European Union's directives and regulations, giving them a particularly sharp, hard edge. Their de facto binding nature has recently been strengthened by means of increasingly rigorous peer reviews, such as those currently conducted by the FSB. ${ }^{2}$ Flawed regulations, including capital regulations, have been held to be among the principal causes of the Global Financial Crisis. This is a significant paradox, since a host of TRNs spent the best part of the last decade building standards that could prevent a financial crisis of the nature and magnitude of the GFC. However, the present discussion will focus more on the need to build institutional capacity and will provide only a cursory discussion of the advantages and flaws of soft-law standards. ${ }^{3}$

Accordingly, I submit that global financial governance needs a radical enrichment of its structures and objectives in four areas: (1) effective supervision and monitoring of systemic risk in global markets, especially

1. See Mario Giovanoli, The Reform of the International Financial Architecture After the Global Crisis, 42 N.Y.U. J. INT'L L. \& POL. 81, 84 (2010); Rolf H. Weber, Mapping and Structuring International Financial Regulation-A Theoretical Approach, 20 EUR. BUS. L. REV. 651, 653 (2009).

2. The FSB conducts both thematic reviews and peer reviews - the results of which may be found on the FSB's website. See Peer Reviews, Fin. STABILITY BD. (last visited Oct. 27, 2012), http://www.financialstabilityboard.org/list/fsb_publications/tid_141/index.htm.

3. A rather extensive discussion may be found in EMILIOS AVGOUleas, GovernanCE OF Global Financial Markets-The LaW, the Economics, THE Politics 213-60 (2012); see also Lawrence G. Baxter, Internationalization of Law-The "Complex" Case of Bank Regulation, in THE InTERNATIONALisATION OF LAW: Legislating, DeCision-Making, PRACTICE, AND EDUCATION 3, 3-37 (Mary E. Hiscock \& William Van Caenegem eds., 2010); Chris Brummer, How International Financial Law Works (and How It Doesn't), 99 GEO. L.J. 257 (2011); David Zaring, International Law by Other Means: The Twilight Existence of International Financial Regulatory Organizations, 33 TEX. INT'L L.J. 281 (1998). 
risk originating in the shadow-banking sector; ${ }^{4}(2)$ effective supervision of big cross-border institutions, so-called globally significant financial institutions (GSIFIs); (3) effective understanding and management of risk in the financial sector, especially risk attached to financial innovation, and standard production; and (4) effective resolution of cross-border financial institutions (CBFIs) and, more importantly, of cross-border financial groups.

In this Article, I will sketch a tighter, more hierarchical and more encompassing model of governance for global financial markets. The most important value of the proposed governance system is its ability to support and further recent reforms protecting the ideal, and enhancing the legitimacy, of open global markets. The proposed global governance structure would have four pillars supported by a similar number of global administrative agencies. Accordingly, this structure is envisaged to comprise first, a global macro-prudential supervisor; second, a global microprudential supervisor; third, a global financial policy, regulation, and knowledge supervisor; and, fourth, a global resolution authority. The suggested governance system presupposes the negotiation and signing of an (umbrella) international treaty governing the most important aspects of international finance.

To many this might sound like an unrealistic academic exercise requiring reform and expenditure on the grandest scale. Several valuable and insightful proposals for global financial governance reform have been criticized or blocked on this basis or on grounds of lack of strong political will for reform. Clearly, no amount of academic writing can change the opposition of big stakeholders like the United States or the European Union to a supranational governance system for global finance. Perhaps, only an imminent financial catastrophe of a scale comparable with the GFC or bigger may be a threat big enough to set political minds

4. Shadow banking is a generic term used to describe a number of financial activities whose common characteristic is that they are not supported by a Central Bank's liquidity operations. In my view, shadow banking normally comprises four forms of financial activity: (1) secured financing by means of repos and rehypothecation; (2) money-market funds; (3) investment vehicles used to facilitate securitization and resecuritization transactions; and (4) hedge funds and other unregulated financial vehicles. However, there is no universally accepted definition. The FSB has offered the first authoritative and formal definition of shadow banking, describing it as "a system of credit intermediation that involves entities and activities outside the regular banking system, and raises i) systemic risk concerns, in particular by maturity/liquidity transformation, leverage and flawed credit risk transfer, and/or ii) regulatory arbitrage concerns." FIN. STABILITY BD., SHADOW BANKING: SCOPING THE IsSuES - A BACKGRound Note OF THE FIN. STABILITY BD. 3 (2011) [hereinafter FSB, SHADOW BANKING], available at http://www.financialstabilityboard.org/publications/ r_110412a.pdf; see also Zoltan POZSAR, ET AL., SHAdOW BANKING, FED. Reserve BD. OF N.Y., STAFF REPORT NO. 458 (2010), available at http://www.newyorkfed.org/research/staff_reports/ sr458_July_2010_version.pdf. 
to the task. On the other hand, academic writing and policy debates should have much to say regarding the optimal form of a governance architecture (structure) for global finance. ${ }^{5}$

The remainder of this Article is divided into six Parts. The next Part describes the evolution of governance structures for global finance throughout the post-war period and includes a discussion of the architecture that has emerged in the post-crisis period. Part III discusses the perceived shortcomings of soft-law structures. Part IV identifies contemporary reforms in the regulation of international finance in a number of key jurisdictions, such as the European Union and the United States, and at the international level and provides a critique of such reforms. Part V sets out the rationale for a "big bang" in the institutional infrastructure governing global finance and outlines the contours of a new governance model that would further undermine the project of economic globalization. Part VI concludes.

\section{A GOVERNANCE SYSTEM IN FLUX}

This Part will describe the three phases of the evolution of the global financial governance system from the Bretton Woods Era (post-1944) to the present times of great turbulence for global finance. It will link each phase of global financial governance development to corresponding market events and requisite financial crises. It will also provide a critical evaluation of the merits and flaws of governance developments in each of the three periods.

\section{A. The Three Periods}

During the first globalization phase, roughly the period between 1870 to World War I, there was no international financial regulation and very little domestic regulation. So the history of modern international financial governance essentially starts with the Bretton Woods conference in 1944, ${ }^{6}$ establishing the IMF and the World Bank, and may be divided into three phases: (1) the Bretton Woods Phase (1947-1997), which also includes the post-Bretton Woods period (from 1972 onward) when the world moved toward floating exchange rates as the fixed system became unsustainable; (2) the post-Asian Crisis period (1998-2008), which saw the evolution of loose global financial governance structures into a tighter regulatory framework, called New International Financial Architecture (NIFA); and (3) the post-2008 period, when national and

5. See AvgOUlEAS, supra note 3, at 429-55.

6. The United Nations Monetary and Financial Conference, commonly known as the Bretton Woods conference, took place in Bretton Woods, New Hampshire, from July 1-22, 1944. 
international policies responding to the causes and consequences of the global financial crisis monopolize the international regulatory reform agenda.

\section{B. The First Period}

The architecture adopted by the Bretton Woods Treaty was based on three main policy ideas or directions. ${ }^{7}$ First, it introduced formal structures in multilateral economic relationships through the establishment of international institutions with strong powers and capacity in terms of management of international monetary relations and facilitation of post-World War II reconstruction (and subsequent development) efforts. The two key institutions were the IMF and the World Bank. Second, the Bretton Woods architecture was based on restrictions of capital flows, a policy that relied on closed financial markets, which retained a largely domestic focus - at least, until the development of the offshore Eurodollar market in the mid-1960s. Third, it intended to liberalize trade and investment flows in the global economic system.

These principles have had a paramount influence on the development of the Western world. The web of postwar economic interactions or relationships among closed national systems was based on and managed through two interlinked international organizations: the IMF and the World Bank. ${ }^{8}$ The third international body that was part of the originally intended framework, the International Trade Organization (ITO), assigned with responsibility to foster liberalization of trade and investment flows, never came to life.

There were no governance arrangements for global finance-a policy choice explained by the fact that the system restricted international capital flows, which were regarded as destabilizing, unlike free trade flows. Restrictions on capital flows and hostility towards open markets reinforced the role of the institutions standing at the center of exchange stability and development finance arrangements. ${ }^{9}$ From the early $1960 \mathrm{~s}$, however, international finance made a comeback to prominence mostly

7. The literature on the Bretton Woods agreement, discussions preceding the conference, and its impact on the development of global finance in the post-World War II years is vast. Two very useful works are JACQUELINE BEST, THE LIMITS OF TRANSPARENCY AND THE HISTORY OF INTERNATIONAL FINANCE (2005) and BARRY EICHENGREEN, GLOBALIZING CAPITAL: A HISTORY OF THE INTERNATIONAL MONETARY SySTEM (2d ed. 2008). For a concise overview, see Richard N. Gardner, The Bretton Woods-GATT System After Sixty-Five Years: A Balance Sheet of Success and Failure, 47 COLUM. J. TRANSNAT'L L. 31 (2008).

8. See Rosa Lastra, Legal Foundations of International Monetary Stability 370 447 (2006).

9. See Douglas W. Arner \& Ross P. Buckley, Redesigning the Architecture of the Global Financial System, 11 MELB. J. INT’L L. 185, 189 (2010). 
due to regulatory restrictions in the United States that fostered offshore capital flows and the establishment of the so-called Eurobonds market. The pace of change accelerated during the 1970s when most large commercial banks in the United States and other developed countries established considerable cross-border business lines and an active presence abroad.

The increasing internationalization of big commercial bank business meant that several (informal) economic cooperation networks or groups, with membership comprising a small number of developed countries, emerged in the 1960s and extended their remit to banking issues. The most known of them is the G-7. Yet the origins of today's complex web of TRNs sitting at the center of global financial governance are traced to another informal body, which "opened for business" in 1974 and gradually dominated the international regulatory agenda. ${ }^{10}$ It was, of course, the Basel Committee on Banking Supervision (BCBS). ${ }^{11}$ The Committee was accountable to the relevant heads of the member central banks and bank supervisors. Its core membership came from an "intriguing" network of central bankers convening their meetings in Basel under the auspices of the Bank for International Settlements (BIS), and it was called the Committee on Banking Regulation and Supervisory Practices.

The first two tasks that occupied the agenda of the BCBS were the cross-border supervision of banks and capital adequacy, mainly focusing on the international banks based in the countries comprising the membership of the BCBS. ${ }^{12}$ Regarding the allocation of supervisory responsibility for international banks, namely, which supervisory authority in the home or host country was responsible for supervising bank branches and subsidiaries across borders, the BCBS, in its initial form, issued the Basel Concordat of 1975 , which was a first attempt to allocate international bank supervisory authority among the host and home regulators and su-

10. The historical events that led to its formation make for interesting reading. The establishment of the Committee, an initiative of the G-10 central bank governors, came in the aftermath of the collapse of the American Franklin National Bank, the Israeli-British Bank in London, and the Bankhaus Herstatt. The latter was a small German bank that stopped operations in the middle of the trading day, causing a major disruption in currency markets and cross-border payments. Although these were non-systemic bankruptcies of three medium size banks, the G-10 central bank governors became concerned with increased risks to banks due to floating exchange rates and the lack of any coordinated cross-border supervision framework.

11. For the early history of BCBS, see generally CHARLES GOODHART, THE BASEL COMMITTEE ON BANKING SUPERVISION: A HISTORY OF THE EARLY YEARS, 1974-1997 (2011).

12. See id.; see also Duncan R. Wood, Governing Global Banking: The Basel Committee and the Politics of Financial Globalisation (2005); Michael P. Malloy, Emerging International Regime of Financial Services Regulation, 18 TRANSNAT'L LAW. 329 (2005). 
pervisors. ${ }^{13}$ The Concordat has since undergone numerous refinements and amendments. A number of Western bank failures, chiefly the collapse of Banco Ambrosiano in 1982 and the Bank of Credit and Commerce International (BCCI) debacle in $1991,{ }^{14}$ exposed the framework as inadequate. $^{15}$ Thus, the Concordat was further refined in 1983 and was effectively replaced in 1992 with a set of minimum standards on the supervision of international banking groups. ${ }^{16}$ These were followed by the publication in 1997 of the Core Principles on Banking Supervision (the Principles) developed by the Committee in cooperation with the IMF and the International Bank for Reconstruction and Development (IBRD). ${ }^{17}$ Although overly optimistic in some cases, the Principles also provided the foundations for building sound banking supervision structures in both the developed and, more crucially, the developing world, and were placed at the heart of the NIFA framework, discussed below.

Another very important set of regulatory standards produced by the BCBS during the 1980s was a risk-based "Capital Adequacy Accord" published in 1988, normally called Basel I. ${ }^{18}$ The main focus of Basel I was on credit (counterparty) risk and much less on other important risks such as currency risk, interest-rate risk, and market risk. In this respect, the framework required a minimum ratio of certain specified constituents

13. See George Alexander Walker, International Banking Regulation: Law, POLICY AND PRACTICE (2001) (discussing the supervision of banking conglomerates and the issue of lead regulator); Richard J. Herring, Conflicts Between Home and Host Country Prudential Supervisors, in INTERNATIONAL FINANCIAL INSTABILITY: GLOBAL BANKING AND NATIONAL REGULATION 201-20 (Douglas D. Evanoff et al. eds., 2007).

14. BCCI operated in seventy-eight countries, had over 400 branches, and had assets in excess of $\$ 20$ billion, making it the seventh largest private bank in the world by assets. BCCI became the subject matter of a notorious regulatory battle when it went into liquidation in 1991 following the eruption of a series of major money laundering scandals to which the bank was heavily involved. More information can be found at Bank of Credit and Commerce International, WIKIPEDIA, http://en.wikipedia.org/wiki/Bank_of_Credit_and_Commerce_International (last visited Oct. 27, 2012).

15. See Duncan E. Alford, Basle Committee Minimum Standards: International Regulatory Response to the Failure of BCCI, 26 GEO. WASH. J. INT'L L. \& ECON. 241 (1992); Susan Emmenegger, The Basle Committee on Banking Supervision-A Secretive Club of Giants?, in THE REgUlation of INTERNATIONAL FinANCIAL MARKETS-PERSPECTIVES FOR REFORM 224-36 (Rainer Grote \& Thilo Marauhn eds., 2006).

16. Basel Comm. on Banking Supervision, Minimum Standards for the Supervision OF INTERNATIONAL BANKING GROUPS AND THEIR CROSS-BORDER ESTABLISHMENT (1992), available at $\mathrm{http}: / / \mathrm{www}$. bis.org/publ/bcbsc314.pdf.

17. See BASel Comm. on BANKing Supervision, Core Principles for EFFeCtive BANKing SUPERVISION AND RELATED METHODOLOGY (2006), available at http://www.bis.org/publ/ bcbs 129.pdf (originally published in Sept. 1997).

18. Joseph J. Norton, The Work of the Basle Supervisors Committee on Bank Capital Adequacy and the July 1988 Report on "International Convergence of Capital Measurement and Capital Standards," 23 INT'L LAW. 245, 259 (1989). 
of capital to risk-weighted assets (RWA). ${ }^{19}$ The prescribed regulatory capital constituents comprised Tier 1 (core) capital, which mainly consisted of shareholders equity, disclosed reserves and retained post-tax profit, and Tier 2 (supplementary) capital, which mainly consisted of subordinated debt. ${ }^{20}$ The Basel I framework endorsed a risk-weighted approach to the assets denominator of the capital assets ratio. ${ }^{21}$ It established a relatively simple methodology for bank assets' risk-weighting with only five risk weights - $0 \%, 10 \%, 20 \%, 50 \%$ and $100 \%$ of asset value - assigned to all types of assets and all types of counterparties, judged by the origin of the counterparty (Organization for Economic Cooperation and Development members versus nonmember countries) and its organizational, legal, or economic nature (sovereigns, credit institutions, corporations), without any separate assessment of its creditworthiness. ${ }^{22}$ For instance, the risk-weighted ratio for all corporate borrowers was $100 \%{ }^{23}$ In addition, following further consultation, the BCBS adopted a target standard capital-to-assets ratio of $8 \%$, of which core capital constituted at least $4 \%{ }^{24}$

Due to the institutional gravitas of participating public organizations, the importance of the countries they represented and the need to level the playing field in the fast growing global market for financial services, ${ }^{25}$ the nonbinding Basel I Accord was adopted by most countries, first in the developed and then in the developing world, regardless of whether they participated in the workings of the BCBS. However, it soon became apparent that the rather rudimentary risk-weight methods of the Basel I Accord, which-ironically, considering the complexity of the Basel II and Basel III frameworks - was thought to be a complex approach that suffered from a number of technical weaknesses.

The continuous internationalization of finance made apparent the need for the establishment of similar informal committees and regulatory fora in other areas of financial activity. For example, a substantial increase in the number of companies that wanted to obtain a listing outside their domestic markets led to formulation of international standards for securities markets, and accounting conventions were given clear prece-

19. Id. at $259-62$.

20. Id. at 260-61.

21. Id. at 260

22. Id. at $260-61$.

23. Id. at 261 .

24. Id. The Basel I Accord and its amendments may be found at Basel Committee-Basel I, BANK FOR INT'L SETTLEMENTS, http://www.bis.org/list/bcbs/tid_21/index.htm (last visited Feb. 10, 2013).

25. Stavros Gadinis, The Politics of Competition in International Financial Regulation, 49 HARV. INT'L L.J. 447, 501-05 (2008). 
dence. Regulatory initiatives emanating from those committees or fora attempted to address the challenges of an increasingly integrated global marketplace fostering the convergence of national regulatory systems. Accordingly, it may be said that the international financial governance structure (architecture) from the middle of the 1980s until 1998 was a loose combination of state-to-state contact groups that comprised the $\mathrm{G}$ groupings, formal international organizations such as the IMF and the $\mathrm{BIS}$, and TRNs such as the BCBS and IOSCO. ${ }^{26}$

In the following sections, I shall provide a concise overview of the developments taking place in the last two, and most important, phases.

\section{Intermediate Phase: A 'New International Financial Architecture' (1998-2008)}

\section{NIFA Overview and Rationales}

During the 1990s, as finance became increasingly global, so did the ensuing financial crises. None of the governance structures of the postBretton Woods period, which were no more than an incremental evolution of the Bretton Woods framework, were adequate to sustain the pressure emanating from the developing wave of financial innovation, liberalization, and market integration that characterized the emergence of financial globalization in the 1990s. In addition, the pre-1998 governance structures were very light and could not provide any kind of forwardlooking regulatory direction beyond market liberalization. Even in advocating the latter, they were just following market developments as well as Washington Consensus policies fervently embraced by the Bretton Woods twins (the IMF and the World Bank) and the U.S. Treasury. Those policies, with their focus on liberalization, opening up markets, and, more importantly, abolition of capital restrictions - without paying any attention to the level of domestic market development or the competence and expertise of regulatory institutions - meant that the Asian Crisis was an accident waiting to happen. And eventually, it happened in the summer and autumn of 1997 and shook global market confidence for some time. $^{27}$

The Asian Crisis made pressing the need for new governance structures for global finance, especially those related to the establishment of early warning systems and regulatory cooperation in the field of crisis

26. See Joseph J. Norton, NIFA-II or 'Bretton Woods-II'?: The G-20 (Leaders) Summit Process on Managing Global Financial Markets and the World Economy - Quo Vadis?, 11 J. BANKING REG. 261, 266-67 (2010).

27. For an overview of the Asian Crisis, see Avgouleas, supra note 3, at 72-74. 
prevention and crisis management. ${ }^{28}$ Accordingly, partly to restore confidence and partly to redress some of the weaknesses of the first phase with its lack of any serious market monitoring, discussions centered on establishing a New International Financial Architecture. The governance, monitoring, or regulatory areas that required strengthening were succinctly summarized by Michael Camdessus, then-head of the IMF, and are paraphrased here: (1) the surveillance of national economic policies, which should be facilitated by fuller disclosure of all relevant economic and financial data; (2) regional surveillance in order to encourage countries in the same region to discipline each other in order to prevent contagion; (3) prudential regulation and supervision in order to lead to (resilient) financial sector reform; (4) more effective structures for debt workouts, both at the national level and international level; (5) capital account liberalization to increase the orderliness of and access to international capital markets; (6) world-wide promotion of good governance and reduction of corruption; and (7) strengthening IFIs, both in terms of resources, authority, and legitimacy, by broadening representation. ${ }^{29}$

In the end, much less happened, and resulting governance structures proved markedly weak and ineffective to forecast, prevent, or manage the GFC that erupted almost a decade later. Yet most regulatory initiatives (with the exception of the radical revision of the Basel I Accord, normally called Basel II) ${ }^{30}$ were in the right direction. It was rather the absence of compulsory monitoring mechanisms and lack of supervisory capacity and of a binding framework for the management of cross-border crises that largely diminished the importance of good work that had been undertaken in the context of NIFA.

The system adopted was mostly concerned with organizing the disparate soft-law networks into a tighter, new structure, facilitated by the establishment of a new informal body, the Financial Stability Forum (FSF). Thus, while NIFA arrangements led to the reinforcement of the role of the IMF and of already existing standard-setting bodies, such as the BCBS and IOSCO, the only truly new body to emerge from it was the FSF.

28. See Barry Eichengreen, Toward a New International Financial Architecture: A Practical Post-Asia AgENDA 13 (1999). In a sense, the foundation stone of the new architecture had been placed before the Asian Crisis when the G-7/8 had gradually wrested the role of central policy coordinator.

29. See Michel Camdessus, Managing Director, Int'l Monetary Fund, The Role of the IMF: Past, Present, and Future, Prepared Remarks at the Annual Meeting of the Bretton Woods Committee (Feb. 13, 1998), available at http://www.imf.org/external/np/speeches/1998/021398.htm; Michel Camdessus, Managing Director, Int'l Monetary Fund, Reflections on the Crisis in Asia, Prepared Address to the Extraordinary Ministerial Meeting of the Group of 24 (Feb. 7, 1998), available at http://www.imf.org/external/np/speeches/1998/020798.htm.

30. See discussion infra Part II.C.6. 
In general, the NIFA system had four levels, incorporating both existing and new international institutions and organizations: (1) intergovernmental (state-to-state contact) groups, mainly combinations of G-7/G$8-10{ }^{31}(2)$ international standard-setting bodies, largely of a technocratic nature; (3) implementation of standards - in principle, a domestic process, but in practice developing countries received technical assistance through a variety of international, regional, and bilateral sources, which also in some cases lobbied for or coerced implementation (for example, through the IMF conditionality); and (4) monitoring implementation of standards, through the FSAP.

Arguably, the fourth level of NIFA was the biggest advancement over preexisting arrangements. For the first time, IFSs were to be supported by a rudimentary level of monitoring at the international level, primarily through the FSAP/ROSC process, moving standards, and standard-setting organizations from a purely agreement-based system to one with a limited level of international review. ${ }^{32}$ Namely, the soft-law system acquired harder edges.

On the basis of the above analysis, we see that standard-setting under NIFA presented six general characteristics: (1) the emergence of an international consensus on the key elements of a sound financial and regulatory system, at least within the G-10 countries; (2) the formulation of principles and practices by international groupings of technocratic authorities with relevant expertise and experience, such as the BCBS, IOSCO, IASB, and IAIS, where the influence of industry is of critical value; (3) market discipline, which for the first time becomes an explicit pillar of supervisory practice, probably as a result and natural extension of Washington Consensus policies; (4) liberalization of access to national markets used as an incentive for the adoption of sound supervisory systems, better corporate governance, and other key elements of a robust financial system; (5) promotion of supervisory independence; and (6) absence of any formal supranational supervisory or regulatory body with standing in international law-meaning that, as a result, the ultimate re-

31. For an overview of the development of the ' $G$ ' groups and their impact on the evolution of international financial regulation, see Baxter, supra note 3.

32. See Douglas Arner, The Developing Discipline of International Law, in INTERNATIONAL ECONOMIC LAW 247 n.4 (Colin B. Picker et al. eds., 2008), available at http://interlaw.ecupl.edu.cn/ uploadfiles/books/International\%20Economic\%20law.pdf (citing Mario Giovanoli, A New Architecture for the Global Financial Market: Legal Aspects of International Financial Standard Setting, in InTERNATIONAL MONETARY LAW: ISSUES FOR THE NEW MiLlenNium 3-60 (Mario Giovanoli ed., 2000); Joseph J. Norton, Qualified Self-regulation in the New Financial Architecture, 2 J. INT'L BANKING Reg. 9 (2000); Rolf H. Weber, Challenges for the New Financial Architecture, 31 H.K. L.J. 241 (2001)). 
sponsibility for policy implementation and supervision rested with national authorities.

Probably the most definitive characteristic of NIFA was the increasing influence that private organizations, especially big banks, through their industry organizations, gradually gained over international standard-setting during this period. Norton has suggested that as such, NIFA might be viewed as "an evolving policy construct in progress, moving towards a new 'governance structure' and reflecting a 'publicprivate partnership' among governments, financial sector authorities, international financial institutions and private international financial institutions in the search for grounding a stable, but viable global financial environment." 33

\section{The Evolution of Standard-Setting Bodies and Financial Standards}

$$
\text { During NIFA }
$$

At the 1997 Denver Summit, the G-7 Heads of State and Finance Ministers placed financial stability at center stage, issuing a Final Report on Financial Stability. ${ }^{34}$ Greater cooperation among supervisors and among the IFIs was strongly encouraged. The Denver Summit advocated the widespread adoption of the BCBS's 1997 Core Principles (revised in 2006) on bank supervision. The G-7 Finance Minister Reports in Cologne (June 1999) and Okinawa (June 2000) specifically followed up, in some detail, and outlined the central components of NIFA targeting financial stability ${ }^{35}$ : (1) stronger macroeconomic policies for emerging economies; (2) IFI (in particular the IMF) reform and strengthening of the operating framework; (3) accurate and timely informational flows and transparency; (4) strong financial regulation in industrial countries; (5) strong financial systems in emerging markets; (6) exchange rate policies; (7) sound accounting standards; (8) reform of legal infrastructure; (9) strengthening of corporate governance; (10) anticorruption and money laundering; (11) technological innovation and adaptation; and (12) risk management.

Although many of the above ingredients of an economic, regulatory, and supervisory framework fostering financial stability are rather

33. Norton, supra note 26, at 272.

34. See G7 Summit 1997, Denver, Colorado, Final Report to the G7 Heads of State AND GOvernment on Promoting Financial Stability (1997), available at http://www.g7. utoronto.ca/summit/1997denver/finanrpt.htm.

35. See G8 Summit 1999, Cologne, Germany, Report of the G7 Finance Ministers to THE KÖLN ECONOMIC SUMMIT (1999), available at http://www.g8.utoronto.ca/finance/ fm061999.htm; G8 SUMMIT 2000, FuKUOKA, JAPAN, REPORT OF THE G-7 FINANCE MinisTERS TO THE HEADS OF STATE AND GOVERNMENT (2000), available at http://www.g7.utoronto.ca/finance/ fm20000708-st.html. 
mainstream, the list above also had surprising inclusions, such as corporate governance.

The main vehicle for the implementation of these initiatives would be a set of "global principles and standards" touching on the following areas: banking regulation; capital markets regulation; insurance supervision; corporate governance; financial conglomerates; payment, settlement, and custody mechanisms; pension funds and collective investment schemes; and accounting and auditing standards. Other areas that were addressed by G-7 Finance Ministers, with mixed results, were such matters as: exchange rate stability; short-term capital flows; regional responses to financial crises; reform of the IFIs; offshore centers; and highly leveraged institutions, such as hedge funds. Other relevant matters that were not tackled with any degree of consistency were: the "prudential regulation carve out," namely the interaction of international prudential standards and the trade liberalization process for financial services; and, even more critically, as it was shown during the GFC, the consolidated supervision of global banks, banking and financial organizations, and financial conglomerates. ${ }^{36}$

\section{The Role of the G-20 During NIFA}

The G-20 was created as a response both to the financial crises of the late 1990s and as a response to the growing recognition that key emerging market countries were not adequately included in the core of global economic policymaking and governance. ${ }^{37}$ Thus, in September 1999, the G-7 Finance Ministers formally announced the establishment of the Group of Twenty Finance Ministers as the successor to the G22/G-33. The G-20 (Finance Ministers) was conceived as a complement to the G-7 (Finance Ministers), not as a replacement. The group's mandate was to be (yet another) informal forum that promoted open and constructive discussion between industrial and emerging market countries on key issues related to global economic stability. By contributing to the strengthening of the international financial architecture and providing opportunities for dialogue on national policies, international cooperation, and international financial institutions, the G-20 helps to support growth and development across the globe. The primary, but not sole function, of

36. See John J. Kirton \& AnTARa Haldar, G7/8 Summit Remit Mandates, 1975-2003 (2003), available at http://www.g7.utoronto.ca/evaluations/factsheet/factsheet_remits.html. For an overview of the G-7 evolving role during the same period, see Peter I. Hajnal \& John J. Kirton, The Evolving Role and Agenda of the G7/G8: A North American Perspective, 7 NAT'L INST. FOR RES. ADVANCEMENT REV. 5, 6-8 (2000), available at www.g7.utoronto.ca/scholar/hajnal_nira.pdf.

37. A detailed description of the G-20 mandate is available at What Is the G20?, G20.orG, http://www.g20.org/index.php/en/g20 (last visited Oct. 27, 2012). 
the G-20 (Finance Ministers) was to consider global and emerging market financial matters and assist in overseeing the international financial system in the post-Asian Crisis period and to encourage the implementation of NIFA standards and structures.

Members would be considered equal - there would be no formal voting. Group positions would be made by consensus. The view of close observers of the group is that the G-20 (Finance Ministers) did provide meaningful leadership and input from 1999 through to 2004 in the context of NIFA implementation and monitoring. Financial stability became an issue of lesser importance after 2004, when the underlying issues were thought to have been properly addressed, and broader financial and economic issues came to dominate the group's agenda, especially the issue of better integration of emerging economies into the globalization process and the world financial system.

From 2005 onward, the G-20 (Finance Ministers) started to focus on balanced and orderly world economic development that included consideration of the volatility in the price of oil and other commodities; completion of the WTO Doha round of negotiations; a sustainable growth agenda; the internal governance reform of the IMF and World Bank (for example, quota arrangements, representation and or legitimacy, effectiveness, and accountability issues); review of the IMF's role and facilities respecting emerging economies; energy security; and the nature of development aid programs. ${ }^{38}$ As a result of the GFC, the G-20 has become the supreme coordination and policymaking body in the field of global financial reform. The G-20's new role in the emerging global financial architecture is discussed below in section D1.

\section{The Evolution of the IMF's Role}

Since the early 1970s, particularly during the 1980s and 1990s with the emergence of an array of sovereign debt crises, including the 19941995 Mexican Crisis and the Asian Crisis, it became apparent that microeconomic, institutional, and structural issues had considerable impact on a country's abilities to implement sound macroeconomic and exchange policies. During the same period, the IMF was in search of a new mission. In the process, the IMF became the main IFI dealing with global financial stability and crisis prevention also adding standard production to its remit. This shift also meant that the IMF's role as a policymaker and policy-giver came under intense criticism. For instance, the Washington Consensus-based liberalization recipe that it gave to most countries in distress during the Asian Crisis was widely regarded to be coun- 
terproductive or outright harmful. ${ }^{39}$ The IMF became a particularly strong mechanism for the promotion of NIFA standards, because compliance with requisite standards and law reform requests could be tied to its "conditionality." ${ }^{40}$ In addition, through the NIFA monitoring arrangements, the IMF became a central player in measuring the effectiveness of IFSs in the NIFA period.

The FSAP and ROSC initiative (jointly conducted by the IMF and the World Bank) was intended to promote long-term financial sector reform. The IMF could assess financial sector robustness through: bilateral country consultations and surveillance ${ }^{41}$ and a range of "financial soundness indicators" ${ }^{42}$ (as part of FSAP program); and multilateral surveillance involving ongoing analysis of global and regional trends, ${ }^{43}$ multilateral consultations on global imbalances, various Early Warning System (EWS) models, and data quality and dissemination channels. For the reasons explained below, these tools proved highly ineffective to forecast and prevent the GFC.

\section{Financial Stability Forum: International Oversight and Coordination}

The FSF was established under the auspices of the G-7 in February 1999 with a mandate to promote international financial stability, improve the functioning of markets, and reduce systemic risk through enhanced information exchange and international cooperation in financial market supervision and surveillance. ${ }^{44}$ The FSF included five different types of members: national authorities, international financial institutions, other international organizations, international financial organizations, and

39. See, e.g., Douglas Arner \& Ross Buckley, From Crisis to Crisis: The Global FinANCIAL System AND Regulatory Failure 55-72 (2011); Joseph E. STIGlitz, GLOBALIZATION AND ITS DISCONTENTS (2003).

40. See Stanley Fischer, First Deputy Managing Director, Int'l Monetary Fund, The IMF and the Financial Sector, Prepared Remarks at Seminar on Financial Risks, System Stability, and Economic Globalization (June 5, 2000), available at http://www.imf.org/external/np/speeches/ 2000/060500.htm.

41. See Bilateral Surveillance Over Members' Policies Executive Board Decision, INT'L MONETARY FUND (June 15, 2007), http://www.imf.org/external/np/sec/pn/2007/pn0769. htm\#decision.

42. See Financial Soundness Indicators (FSIs) and the IMF, INT'L MONETARY FUND (Nov. 30, 2011), http://www.imf.org/external/np/sta/fsi/eng/fsi.htm.

43. Two of the main outputs are the IMF's annual World Economic Outlook and the semiannual Global Financial Stability Report. The IMF used to see "multilateral surveillance" as being the most important of its functions and described it as: "[T]he surveillance of economic linkages and policy spillovers between countries as well as international economic and market developments." InT'L MONETARY Fund, AN EVAluATION OF THE IMF's Multilateral SuRVEILlanCE 7 (2006), available at $\mathrm{http}: / / \mathrm{www}$.imf.org/external/np/ieo/2006/ms/eng/pdf/chap1.pdf. For a detailed description of the IMF, see $i d$. at 7-13.

44. See George A. Walker, A New International Architecture and the Financial Stability Forum, in ESSAYS INTERNATIONAL FINANCIAL LAW AND ECONOMICS NO. 24 (1999). 
committees of central bank experts. The FSF created a number of ad hoc working groups to develop recommendations on specific issues, including highly leveraged institutions, capital flows, offshore financial centers, and implementation of standards, incentives to foster implementation of standards, deposit insurance and e-finance. Arguably, the most important part of the FSF's original mandate was the strengthening of surveillance and supervision of the international financial system. Specifically, the FSF was called to assess vulnerabilities affecting the international financial system; identify and oversee the action needed to address these vulnerabilities; and improve coordination and information exchange among the various authorities responsible for financial stability.

Eventually, the FSF constituents agreed upon twelve key areas of standards, grouped into three main categories and known as the Compendium. Each set of key standards was supported by a methodology for assessment and implementation and a variety of related principles, practices, and guidelines. The FSB has updated the Compendium to add to the list of key standards. ${ }^{45}$ Selection of areas and designation of key

45. The key standards represent minimum requirements for good practice and often refer to more than one aspect of the financial system. They also vary in terms of level of international endorsement. A broad categorization of the endorsed standards may be grouped as follows:

Macroeconomic Policy and Data Transparency

(1) Monetary and financial policy transparency: "Code of Good Practices on Transparency in Monetary and Financial Policies," issued by the IMF.

(2) Fiscal policy transparency: "Code of Good Practices on Fiscal Transparency," issued by the IMF.

(3) Data dissemination: "Special Data Dissemination Standard/General Data Dissemination System," issued by the IMF.

Institutional and Market Infrastructure

(4) Insolvency: "Insolvency and Creditor Rights," issued by the World Bank.

(5) Corporate governance: "Principles of Governance," issued by the OECD.

(6) Accounting: "International Accounting Standards (IAS)," issued by the IASB.

(7) Auditing: "International Standards on Auditing (ISA)," issued by IFAC.

(8) Payment and settlement: "Principles for Financial Market Infrastructures," issued by CPSS and IOSCO.

(9) Market integrity: "Recommendations on Combating Money Laundering and the Financing of Terrorism \& Proliferation," issued by FATF.

Financial Regulation and Supervision

(10) Banking supervision: "Core Principles for Effective Banking Supervision," issued by BCBS.

(11) Securities regulation: "Objectives and Principles of Securities Regulation," issued by IOSCO.

(12) Insurance supervision: "Insurance Core Principles," issued by IAIS.

Key Standards for Sound Financial Systems, Fin. STABILITY BD., http://www.financialstability board.org/cos/key_standards.htm (last visited Nov. 12, 2012). More recently the FSB has added the following standards:

(1) IOSCO Recommendations for Central Counterparties, which set out comprehensive standards for risk management of a central counterparty, to facilitate the reform of overthe-counter derivatives markets; 
standards was something of a bottom-up process, with standard setters choosing to address and promote their respective standards to the intergovernmental groupings such as the G-7 and the international financial institutions for adoption and support. Nonetheless, the standard-setting process acquired homogeneous characteristics.

The FSF's legacy is not as successful as it could have been. ${ }^{46}$ Apart from problems with the selection of the key standards, its very nature was unclear, perceived by some as a "think tank with nowhere to go,"47 probably an accurate description given its invisibility and narrow membership. The opaque nature of soft law making was also another factor that undermined the FSF's legitimacy and might have also prejudiced the effectiveness of the selected standards and their implementation. Therefore, it was not surprising that the G-20 (Leaders' level) decided at its Washington (November 2008) and London (April 2009) Summits to replace the FSF with the FSB in order to strengthen coordination of standard production and implementation. Nonetheless, as explained in the next section, the FSB suffers many of the shortcomings that plagued the FSF.

\section{BCBS Develops a Risk-Sensitive Capital Framework}

One of the central - and least successful - parts of NIFA was the Basel II capital adequacy framework. In the late 1990s, the weaknesses of Basel I led to an extensive round of negotiations for the drafting of a new accord. Given the many changes in the financial services industry and the growing difficulties experienced by supervisors with the complexity and changing nature of risk in global financial markets, the starting point was to emphasize the role of market discipline in risk management. ${ }^{48}$

In June 1999, the BIS issued a proposal that would significantly change the capital adequacy Accord through extensive revision and re-

(2) the Core Principles for Effective Deposit Insurance Systems by the BCBS and IADI.

The FSB will also add in the future 'one or more standards on resolution regimes for financial institutions.

Fin. Stability BD., Progress in the Implementation of the G20 Recommendations for STRENGTHENING FinANCIAL STABILITY 9 (2011), available at http://www.financialstability board.org/publications/r_110415a.pdf.

46. Cally Jordan, The Dangerous Illusion of International Financial Standards and the Legacy of the Financial Stability Forum 3-4 (Melbourne Law Sch. Legal Studies, Research Paper No. 501, 2010), available at $\mathrm{http} / / /$ papers.ssrn.com/sol3/papers.cfm?abstract_id=1662609.

47. John Eatwell, The Challenges Facing International Financial Regulation, FIN. POL'Y FORUM, July 2001, at 14, available at http://www.financialpolicy.org/DSCEatwell.pdf.

48. As Daniel Tarullo (a current U.S. Federal Reserve Governor and a professor of law) has observed, Basel II consultation resembled trade negotiations and, at the outset, no national regulator had a clear idea what outcome they desired. DANIEL K. TARULLO, BANKING ON BASEL: THE FUTURE OF INTERNATIONAL FINANCIAL REGULATION 87 (2008). 
finement of Basel I and by providing an alternative approach to measuring risk that would bring the capital framework closer to global market risk management practices. ${ }^{49}$ Following several rounds of consultation, the revised Accord was finally published in June $2004^{50}$ and further additions were released in 2005. ${ }^{51}$ The Basel II framework for the assessment of the capital adequacy of international credit institutions and monitoring of their compliance was based on three pillars: Pillar 1 provided "minimum capital requirements"; Pillar 2 described the process for the "supervisory review" of capital adequacy; and Pillar 3 provided the mechanisms to facilitate and enforce "market discipline" through public disclosure. $^{52}$

Pillar 1 involved significant changes in capital adequacy regulation. More specifically, although Pillar 1 reproduced the basic provisions of Basel I, it also introduced important changes in how aspects of credit risk were to be calculated and it expanded the range of risks addressed by capital adequacy standards to include operational risk. ${ }^{53}$ Three different options were available to banks to measure the regulatory capital that they had to assign to each asset. ${ }^{54}$ The first option was the "standardized approach," ${ }^{, 55}$ intended to be used by less sophisticated institutions. Although it was based on Basel I, this approach used enhanced risk sensitivity measures, as it differentiated among exposures to different classes of bank clients. ${ }^{56}$ Risk weightings for sovereign and corporate exposures could be calculated according to external credit assessments provided by rating agencies or public organizations such as the OECD ${ }^{57}$ The second and third options were based on the new "Internal Ratings Based Approach" (IRB). ${ }^{58}$ Under the IRB, international banks were required to establish their own internal methods for assessing the relative risks of their assets in determining the capital requirement for given exposures. ${ }^{59}$ In this mode, the "foundation" version of the IRB for risk management

49. See Basel Comm. on Banking Supervision, A New Capital Adequacy Framework (1999), available at http://www.bis.org/publ/bcbs50.pdf.

50. Press Release, Bank for Int'l Settlements, G-10 Central Bank Governors and Heads of Supervision Endorse the Publication of the Revised Capital Framework (June 26, 2004), available at http://www.bis.org/press/p040626.htm.

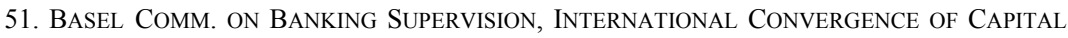
MEASUREMENT AND CAPITAL STANDARDS: A REVISED FRAMEWORK (2006), available at http://www.bis.org/publ/bcbs128.pdf [hereinafter BASEL II ACCORD].

52. Id. at $2-3$.

53. Id. at 12 .

54. See id.

55. Id.

56. Id. at 19-20.

57. Id. at 20.

58. Id. at 12 .

59. Id. at 52. 
made limited use of internal Value at Risk (VaR) models. ${ }^{60}$ The advanced IRB made much wider use of VaR and was meant for the largest and most sophisticated financial institutions. ${ }^{61}$

Following the eruption of the GFC, the Basel framework was subjected to severe criticism. ${ }^{62}$ First, the GFC proved that Basel II relied excessively on risk-modeling and credit ratings that fostered not only regulatory arbitrage (similar to Basel I) but also a relentless push toward ever-reduced equity capital cushions, the only form of regulatory capital that matters in the event of a crisis. ${ }^{63}$ Second, the sophistication of financial institutions meant that the supervisor had to ultimately rely on the superior risk-modeling expertise of the institution or of the CRAs, making "supervisory review" ineffective. ${ }^{64}$ Third, market discipline proved to be much less effective than the previously assumed monitoring mechanism for several reasons. ${ }^{65}$ Market participants have limited ability to monitor a bank's exposures in light of the very complex instruments financial institutions trade with each other and the ability to hide exposures through shadow-banking vehicles. ${ }^{66}$ Complexity, opacity, and interconnectedness just strengthened the "too-big-to-fail" problemweakening, if not obliterating, shareholders' and creditors' incentives to properly monitor the market behavior and business policies and practices of the banks concerned. ${ }^{67}$ Fourth, by focusing on individual banking institutions (the micro-prudential perspective), it largely ignored the impact of trading and market behavior of such institutions on the financial system as a whole and its stability (the macro-prudential perspective) ${ }^{68}$ Fifth, it provided no framework for the creation of liquidity cushions within highly geared financial institutions. ${ }^{69}$ As has already been explained, this was one of the main causes of the GFC. Finally, the framework was procyclical, allowing increased credit flows to the economy during the period of growth, feeding asset bubbles, while banks found themselves inadequately capitalized when the various asset bubbles burst and national economies entered into recession. ${ }^{70}$

60. Id. at 80

61. Id. at 84-85.

62. See AVGOULEAS, supra note 3, at 198.

63. Id.

64. Id.

65. Id. at 198-99.

66. Id. at 199 .

67. Id.

68. Id.

69. Id.

70. Id. at 133 . 


\section{Implementation-Monitoring and the FSAP Surveys}

An important element of the standard-setting process involves monitoring the implementation of international standards. While primarily a domestic process, implementation is supported by a range of assistance mechanisms. Monitoring mainly takes place at the international level through the international financial institutions, especially the IMF and World Bank. Specifically, the IMF works through its annual Article IV consultations. $^{71}$

FSAP itself consists of three main components: (1) systematic analysis of financial soundness indicators (FSIs) and stress tests; (2) assessments of standards and codes; and (3) assessment of the broader financial stability framework, including systemic liquidity arrangements, governance and transparency and financial safety nets and insolvency regimes. ${ }^{72}$ Upon completion of FSAP surveys, the joint IMF and World Bank team prepares a confidential memorandum presenting their findings. The IMF uses those documents to prepare a Financial Sector Stability Assessment (FSSA), which is presented to the Executive Board each year. It is also often used in connection with the Fund's surveillance role under its biennial Article IV consultations. FSAP surveys are also used to facilitate the IMF's role in the production of financial standards and codes of practice as well as the World Bank's development activities, enabling it to provide higher quality and more targeted technical assistance. The production of FSAP surveys is a separate activity from the IMF's role in compiling ROSCs, yet the latter is strongly based on FSAP findings. In recent years, the IMF and the World Bank have attempted to integrate the FSAP and ROSC processes into their evolving development agenda.

FSAP surveys eventually became the subject of strong criticism due to their failure to give any warning signs before the eruption of the GFC. Their practice in the pre-GFC era had, in general, shown several weaknesses.

Arguably, FSAP's inadequacies did not always relate to weak conduct of the surveys but were symptomatic of the bigger global governance weaknesses of the NIFA era and beyond. First, in the absence of an international treaty imposing a compliance commitment or any other contractual (legal) obligation, akin to that which may be imposed on IMF or World Bank borrowers through conditionality, cooperation with FSAP was requested voluntarily. As late as 2006, approximately twenty to $25 \%$

71. Factsheet: The Financial Sector Assessment Program (FSAP), INT'L MONETARY Fund, http://www.imf.org/external/np/exr/facts/fsap.htm (last visited Oct. 27, 2012).

72. Id. 
of countries that were systemically important, had vulnerable financial systems, or both - key criteria endorsed by the IMF and the World Bank Boards for FSAP surveys - had not been assessed, including Turkey, Indonesia, China and, most importantly, the United States. ${ }^{73}$ In addition, the absence of a global regulatory supervisory authority to follow up FSAP findings and recommend policy under the threat of sanctions meant that timely and accurate observations as part of the FSAP, as was the case with Iceland, went unheeded.

Among the FSAP's many weaknesses was the fact that the voluminous data was of variable quality and not always capable of quantitative processing because it was also incomplete. In addition, the questions asked in the context of the FSAP process were not always those that should have been asked in the first place. Often this was due to the fact that it tried to measure the implementation of monolithic standards on markets of varied structure and depth as are those of developing countries. Also, the carrying out of FSAP inspections suffered from major inconsistencies, ${ }^{74}$ and IMF and World Bank staff's lack of familiarity with the national economies under scrutiny made matters even worse. One reason for these inconsistencies is an alleged lack of skills and expertise by the FSAP teams. Another was the fact that FSAP teams mostly comprised economists who were called to examine the implementation of financial regulations, a job that is, arguably, much better carried out by suitably qualified lawyers, especially when it involves compliance check box methods. This could have led FSAP staff to draw wrong conclusions on an inspected country's regulatory robustness. In addition, updating FSAPs, especially in view of the constantly evolving methodologies, was problematic. For any country submitting to the highly intrusive and labor intensive FSAP process, which involved facilitating the carrying out of the surveys by large teams of financial experts, FSAP was a significant burden, and even more so for smaller countries with limited resources.

The essentially domestic focus of the FSAP process did not capture cross-border linkages, influences, risk transmission channels, or institutional interconnectedness. This eliminated FSAP's usefulness in the case of SIFIs that maintained very large cross-border deposit and asset

73. The United States finally permitted an FSAP to be conducted in the wake of the global financial crisis. See INT'L MONETARY Fund, REPORT ON THE EVALUATION OF THE FINANCIAL SeCtor AsSESSMENT PROGRAM (2006), available at http://www.imf.org/external/np/ieo/2006/ fsap/eng/pdf/report.pdf. The IMF has issued a subsequent review explaining what remedial actions the Fund and its members have taken to strengthen FSAP. See INT'L MONETARY FUND, THE Financial Sectors Assessment Program After Ten YeArS-EXPERIENCES AND REFORMS FOR THE NEXT DECADE (2009), available at http://www.imf.org/external/np/pp/eng/2009/082809B.pdf.

74. Jordan, supra note 46, at 21. 
bases and attendant revenue lines. Namely, the riskiness of the most important institutions in any given economy was largely under-surveyed and, as a result, risks went under-reported. Moreover, the standards themselves were in some cases problematic and backward-looking. In the case of IOSCO Principles of Securities Regulation, the standards were dominated by efficient market ideology and U.S. notions of tight regulation of retail equity markets, ignoring the role of other markets, especially where hedge funds were very active. ${ }^{75}$ This meant that FSAP surveys missed areas and issues of critical interest, especially the role of unregulated markets in propagating systemic risk. Since then, IOSCO has taken stock of these inadequacies and revised its standards.

\section{A Critique of NIFA}

Well before the eruption of the GFC, globalized markets had posed very serious challenges to a system that was largely based on national regulatory or supervisory competence, even within the European Union. The three main concerns were: (1) regulatory arbitrage, which was intensified through the use of shadow-banking schemes; (2) intensification of regulatory competition, caused by the supervisor's tendency or official mandate to attract business to their jurisdiction, which can trigger a race to the bottom; and (3) the globalized nature of market risks, especially those linked to market abuse, and systemic risks. ${ }^{76}$

In addition, NIFA did not include a comprehensive financial sector or system reform package that would factor in relevant developmental, trade, and investment objectives. There was also a striking absence of focus on the actual fragility of developed countries' financial systems. Furthermore, the NIFA structures were especially weak when it came to crisis warnings and cross-border crisis management. ${ }^{77}$ As a result, NIFA structures proved seriously inadequate to prevent the GFC.

\section{The Emerging Architecture}

While the response to the Asian financial crisis had a very strong international dimension (centered on the IMF), the majority of policies seeking to contain the severity and consequences of the GFC had a

75. Press Release, Int'l Org. Sec. Comm., Global Securities Regulators Adopt New Principles and Increase Focus on Systemic Risk (June 10, 2010), available at http://www.iosco.org/news/ pdf/IOSCONEWS188.pdf. See INT'L ORG. SEC. COMM., UNREGULATED FINANCIAL MARKETS AND PRODUCTS: FINAL REPORT 3 (2009) (“All systemically important financial markets and instruments should be subject to an appropriate degree of regulation and oversight, consistently applied and proportionate to their local and global significance.”).

76. See Ethiopis Tafara \& Robert J. Peterson, A Blueprint for Cross-Border Access to U.S. Investors: A New International Framework, 48 HARV. INT'L L.J. 31, 36, 40, 50-52 (2007).

77. Arner \& Buckley, supra note 9, at 7. 
strong domestic or regional (in the case of the European Union) dimension. At the international level, coordination initially took place through the G-7 and, at the multilateral level, through the FSF and the world's major central banks. However, from November 2008 onward, the G-20 became the main body for coordination of policies intended to avert a global economic catastrophe and the meltdown of the international financial system. During the initial phases, which mainly affected developed countries, the IFIs and the WTO played a marginal role. Only when the tremors spread beyond the G-7 countries, and especially when the crisis was transformed into a sovereign debt crisis, did the IMF take center stage. On the other hand, the WTO has remained sidelined, beyond discussions about the completion of the Doha round, possibly a serious strategic mistake as trade liberalization and financial stability should, arguably, be realigned at the global level.

The reform initiatives so far have been twofold: the reform of supervisory structures to facilitate regulatory cooperation and crisis management; and the replacement and enhancement of international standards to radically improve the quality of international financial regulation. The architectural changes in the period after the onset of the GFC in the international context broadly comprise, first, the emergence of the G$20{ }^{78}$ second, FSF's successor the FSB, whose main mission is the coordination of the standard-setting process and oversight of the standardsetting TRNs; ${ }^{79}$ and, third, the reformed IMF. ${ }^{80}$ Each of these institutions has a different membership, mission, and legal status. Finally, an important role is envisaged for the joint regulatory bodies called "supervisory colleges," which are assumed to provide coordination and leadership in the supervision of large systemically important cross-border financial institutions.

\section{The Emergence of the G-20}

In terms of international financial governance, the most important development brought about by the GFC is the emergence of the G-20 as the principal coordinating body, following the formation of a government

78. See Claudia Schmucker \& Katharina Gnath, From the G8 to the G20: Reforming the Global Economic Governance System, (GARNET Working Paper No. 73/09, 2010), available at http://www.g20.utoronto.ca/biblio/7310.pdf.

79. Douglas W. Arner \& Michael W. Taylor, The Global Credit Crisis and the Financial Stability Board: Hardening the Soft Law of International Financial Regulation?, 32 U. NeW S. WALES L.J. 488, 489-90 (2009).

80. For an overview of the emerging architecture, see generally INTERNATIONAL MONETARY \& FinanCial LaW: The Global Crisis (Mario Giovanoli \& Diego Devos eds., 2010); Giovanoli, supra note 1. 
leaders' level within this group. ${ }^{81}$ Apart from severe shortcomings of TRNs when it came to cross-border crisis management and coordination, the limited capacity and ability of IFIs made them an inadequate means to coordinate meaningful international crisis management efforts. ${ }^{82}$ Arguably, the wide array of economic policies and regulatory reforms that had to be adopted to counter the effects of the GFC made the assumption of a leading role by the G-20 governments the only reasonable response in the circumstances.

At the April 2009 London Summit, the G-20 leaders reached a broad agreement to enhance the representation of emerging economies to better reflect their growing economic influence. The G-20 now comprises the G-7 countries (Canada, France, Germany, Italy, Japan, the United Kingdom, and the United States) and the biggest emerging economies: Argentina, Australia, Brazil, China, India, Indonesia, Korea, Mexico, Russia, Saudi Arabia, South Africa, and Turkey. ${ }^{83}$ The European Union is represented through the E.U. Presidency and the European Central Bank (ECB), bringing the membership tally to twenty. Moreover, the IMF Managing Director, the Chair of the IMF IMFC, the Chair of the IMF Development Committee, and the President of the World Bank are ex officio members of the G-20. Other formal international organizations, such as the Organisation for Economic Cooperation and Development (OECD), are involved in certain areas. However, the WTO was not formally included - a weakness in the framework.

The nineteen country members of the G-20 plus the European Union represent approximately two-thirds of the world's population, $80 \%$ of world trade, and $90 \%$ of the world's GDP. ${ }^{84}$ However, the G-20's scant resources and wide and fluid agenda puts in doubt the ability (and willingness) of the G-20 (Leaders' level) to play a leadership role in the field of financial stability on a permanent basis. ${ }^{85}$ It follows that because the G-20 represents only a temporary solution to the global challenge of fi-

81. For an analytical account, see Norton, supra note 26 , at 281-89. A critical account is provided by Ngaire Woods, The G20 Leaders and Global Governance (Oxford Univ. Global Econ. Gov't Program, Working Paper No. 2010/59, 2010), available at http://www.globaleconomicgov ernance.org/wp-content/uploads/Woods-2010-The-G20-and-Global-Governance.doc.pdf.

82. David Zaring, International Institutional Performance in Crisis, 10 CHI. J. INT’L L. 475, 493-94 (2010). 2010).

83. Members, G20.ORG, http://www.g20.org/index.php/en/members (last visited Feb. 10,

84. Statistics, G20.ORG, http://www.g20.org/index.php/en/numeralia (last visited Feb. 10, 2010).

85. Zaring, supra note 82 , at 492 . 
nancial stability governance, "a regulatory vacuum remains to be filled." $" 86$

\section{The IMF}

Under the new governance arrangements, mostly agreed to by the G-20 (Leaders' level), the IMF is envisaged to play a key role in the global financial architecture emerging as a result of the GFC. First, the IMF has remained the most important global institution for macrofinancial supervision. Second, it will conduct a strengthened FSAP, as all G-20 members have agreed to subject themselves to FSAP surveys and support the transparent assessment of their national regulatory systems. It will also conduct early warning exercises in cooperation with the FSB. Of course, the IMF is not a selective club of a number of influential countries. It is a full-fledged international organization with solid institutional foundations and universal membership, although its quota-based decisionmaking process still favors the United States and European members. It has the potential to be much more representative than any of the "Gs." In addition, the G-20 did not rule out the possibility of making FSAP and ROSC surveys compulsory through a future revision of the IMF's Articles of Agreement.

Even if the FSAP and ROSC surveys were made compulsory for IMF members, the question would remain as to what the IMF should do with that information because it cannot be acted upon by the Fund itself, which lacks the powers of an international supervisor who could intervene if national authorities showed complacency in the face of stark warnings. Clearly, transforming the IMF, which is also the global lender of last resort for sovereign borrowers, into the sole supervisor of global markets would concentrate excessive power into the hands of a global institution, which is already very powerful and has a rather mixed record when it comes to crisis management. Therefore, a different way must be found to build cross-border supervisory and crisis resolution capacity. I suggest in a subsequent section that this may be done by strengthening IMF's supervisory capacity as part of a broader regulatory structure charged with the governance of international finance.

\section{From the FSF to the FSB}

The Washington and, more conclusively, the London Summit of the G-20 (Leaders' level) led to the reconstitution of the much maligned

86. Eric J. Pan, Challenge of International Cooperation and Institutional Design in Financial Supervision: Beyond Transgovernmental Networks, 11 CHI. J. INT'L L. 243, 245 (2010); see Giovanoli, supra note 1, at 105. 
FSF, which became a global Financial Stability Board, although it lacks, like the FSF, any international law standing. The FSB is much more representative than its predecessor because its membership includes representatives of twenty-four countries. In addition, all major IFIs, such as the IMF, the World Bank, and the ECB, and all major standard-setting bodies, such as the BCBS, IOSCO, and IAIS, are members of the FSB. Also, unlike the BCBS or other TRNs, FSB's membership is subject to regular reviews, giving the organization a strong characteristic of openness.

The FSB has inherited the FSF's original mandate of setting standards to assess vulnerabilities affecting the financial system, identifying and overseeing actions required to address such vulnerabilities, and promoting coordination and information sharing among authorities responsible for financial stability. It has also been assigned a number of key additional tasks: (1) monitoring and provision of advice on market developments and their implications for regulatory policy; (2) monitoring and provision of advice on best practices for meeting regulatory standards; (3) undertaking joint strategic reviews of the policy development work of the ISSBs to ensure their work is timely, coordinated, and focused on priorities and addressing gaps; (4) setting guidelines for and supporting the establishment of supervisory colleges; (5) supporting contingency planning for cross-border crisis management, particularly with respect to systemically important firms; and (6) collaborating with the IMF to conduct EWS exercises. ${ }^{87}$

The division of responsibility between the IMF and the FSB did not prove a thorny issue. The IMF has remained the principal institution responsible for surveillance of the global financial system and monitoring of standards implementation through the FSAP and ROSCs. The FSB is taking the lead in terms of standard setting and coordination of standardsetting bodies. ${ }^{8}$

It has been argued by expert commentators that the FSB constitutes a marked improvement over FSF's fading regulatory profile and weak mandate. ${ }^{89}$ However, the uncertainty surrounding the FSB in terms of accountability lines and status is considerable, raising the same questions as the operation of the BCBS. For example, while the FSB was reconstituted by the G-20, there is no clear line of reporting to this body. In addition, like the FSF, the FSB remains an informal organization, which in itself is neither a (self-standing) standard-setting entity nor a supervisory

87. See Mandate, Fin. STABILITY BD., http://www.financialstabilityboard.org/about/man date.htm (last visited Oct. 27, 2012).

88. AVGOULEAS, supra note 3, at 208.

89. Giovanoli, supra note 1, at 108-09. 
authority. ${ }^{90}$ As a result, it "has no institutional powers and can neither force any country (whether a member of the FSF/FSB or not) to implement the standards approved by it nor impose any sanctions." ${ }^{91}$ In addition, its lack of a standing in international law means that the FSB does not have any means of formal representation. Also, a number of unresolved questions surround its standard-setting and coordination mission. For instance, it is by no means clear whether the FSB is the ultimate arbiter with regard to design and adoption of IFSs, nor does its mandate extend to rendering the other ISSBs accountable to the Board. ${ }^{92}$ This lack of clear lines of responsibility, in terms of IFS production and implementation, could become a rather contentious issue when a controversial new IFS (or a set of IFSs), which is not based on broad consensus yet generates distributional conflict, is imposed on national jurisdictions. ${ }^{93}$

It is widely expected that the FSB will provide a smoother framework for standard setting and implementation, although it also adds yet another layer in the already over-complicated decisionmaking and standard-setting system for global finance. ${ }^{94}$ However, its lack of formal legal status, its inability to impose sanctions for noncompliance, and its lack of clear accountability lines are bound to prove problematic. Finally, the mandate given to the FSB is not the answer to the biggest questions of international regulatory coordination that have arisen in the course of the GFC. ${ }^{95}$ In summary, these are, first, the supervision of SIFIs with strong cross-border presence; second, the issue of burden sharing for resolutions of such institutions, which during the GFC fell disproportionately on home country Treasuries; and third, international crisis management coordination to contain spillovers created by actions of weak national regulators (as was the case with Icelandic regulators) or regulators that pursue a narrow national interest agenda.

Accordingly, if G-20 governments do not want to keep fighting the last crisis, which is the underlying rationale for the gigantic wave of recent reforms, the role of the FSB will have to change. The effortless way in which the FSB has been involved in peer review to test compliance with its standards and its close involvement with supervisory colleges shows that the best mission for an FSB reconstituted in the guise of an international law body is to become the formal micro-prudential regulator of G-SIFIs. Another formal body within the regulatory structure pro-

90. Id. at 109-10.

91. Id. at 110

92. Id. at 114,161

93. Id. at $114-15$.

94. AVGOULEAS, supra note 3, at 209.

95. Id. 
posed in section four below could perform the FSB's duties in terms of standard setting, bringing under its umbrella of oversight the BCBS, IOSCO, and other regulatory TRNs of central importance for the regulation of contemporary financial markets.

\section{The Supervisory Colleges}

Following the G-20 summit in Washington, which stressed the importance of international regulatory coordination through the formation of collaborative groups of supervisors, the FSF/FSB initiated the process for the formation of supervisory colleges for (in the first place) thirty large and complex financial institutions judged to have global systemic significance. Supervisory colleges are multilateral working groups of national authorities involved in the supervision of an international banking group. They are seen as a practical mechanism to closing the gap in the supervision of large cross-border financial groups with multiple stakeholders in a variety of countries. Thus, the colleges are established to enhance effective, consolidated supervision of cross-border financial groups on an ongoing basis, including monitoring any threat that the group poses for the stability of the financial system of the countries involved. However, the colleges do not interfere with existing bilateral or multilateral supervisory arrangements, nor do they act as a replacement to national regulators. A substantial part of their work (and a key to their success) is overseeing the drafting of recovery and resolution plans by those groups (so-called "living wills"), which are meant as the principal means to simplify corporate structures, to make supervision more effective, and to avoid Lehman-type predicaments in the resolution of crossborder groups.

The BCBS concluded its consultation on Good Practice Principles with respect to supervisory colleges in 2010 and published a final set of principles, ${ }^{96}$ which provide college objectives, structure and decisionmaking processes, and procedures for communication and information sharing between participating national supervisors. Although a significant improvement over pre-GFC arrangements for cross-border financial group supervision, the colleges are not international supervisors for the groups concerned. All enforcement powers remain vested with national authorities. In addition, there are a number of different colleges supervising the same international banking groups, creating room for confusion. Also the colleges do not provide, in the absence of burdensharing arrangements, any comfort that, in the event of a crisis, they will

96. Basel Comm. on Banking SuPervision, Good Practice Principles on Supervisory COLLEGES (2010), available at www.bis.org/publ/bcbs177.pdf. 
not fall apart with each supervisor trying to guard narrowly defined national interests.

\section{E. Summary}

This section has charted the evolution of global governance structures from the Bretton Woods conference in 1944 to date. The relevant analysis has progressed from the early post-World War II years of protectionism and closed financial markets, when the Bretton Woods twins were shaping their mandates, to the period in the 1970s when the IMF especially had to reinvent its role. The sovereign debt crises of the 1980s and 1990s and the development needs of the post-colonial world meant that, on the eve of the Asian Crisis, the two institutions stood as tall as ever. In the meantime, their limited regulatory mandate and the degree of inflexibility ingrained in their statutes and operations meant that much more cooperative forms of international regulation had to be found to address the challenges posed by the growth of international finance in the post-Bretton Woods period. Since the 1970s, when global markets showed the first signs of integration, up to the 1990s and the 2000s, when integration acquired a frenetic pace, the regulation of international finance was mostly based on informal TRNs such as the BCBS and stateto-state contact groups such as the various "G" groupings.

The Asian Crisis meant a tightening of governance structures but in a way that would coopt the ever more powerful interests of the global (Western) finance industry. Thus, the NIFA governance paradigm had at its center the TRNs and their standards in the production of which the private sector had a critical say. ${ }^{97}$ This was coupled by a weak system of monitoring undertaken by the IMF and the World Bank. The NIFA structures proved unable to prevent, or even predict, the GFC, and some of their most important segments, such as the Basel capital standards, seem to have contributed both to the buildup and the severity of the GFC. This accentuated the case for far-reaching reforms. The United States, the European Union, and the TRNs have introduced critical reforms in a number of areas from capital standards to regulation of OTC derivatives trading. They particularly try to address moral hazard emanating from the operation of "too-big-to-fail" institutions. ${ }^{98}$

97. See Eleni Tsingou, Transnational Governance Networks in the Regulation of Finance-The Making of Global Regulation and Supervision Standards in the Banking Industry, in THEORETICAL Perspectives on Business and Global Governance: Bridging TheORETiCAl Divides 138-53 (Morten Ougaard \& Anna Leander eds., 2010).

98. For an overview of FSB's new regulations on G-SIFIs and the emerging U.A., E.U., and U.K. regimes dealing with the problem of the "too-big-to-fail" institution, see AVGOULEAS, supra note 3 , at ch. 7. FSB's initiatives in this field range from standards on enhanced supervision to the resolution of "two-big-to-fail" institutions. The complete the list of requisite FSB policy documents 
However, the governance architecture that has emerged, which has witnessed the rise of the G-20 and the reconstitution of the FSF and FSB, does not provide any radical changes from the past. It is plausibly argued that "although, the soft law approach clearly failed to prevent or resolve the GFC, the solution adopted so far is [a] harder version of the soft law approach." ${ }^{99}$ Standard-setting remains the job of the TRNs such as the BCBS, IOSCO, etcetera, albeit under closer coordination through the FSB. As a result, the emerging architecture leaves largely unaddressed the regulatory and supervisory challenges already discussed. In addition, yet again, the architecture neglects the mutually reinforcing relationship between financial stability and economic development. Therefore, the important reforms outlined above might just produce another failure due to the timidity of interventions pertinent to governance structures, ending up as an excellent means for fighting the causes of the last crisis.

The need for forward-looking governance structures that will provide formal systemic risk and G-SIFI supervision as well as an international cross-border resolution regime for those financial institutions is as great as ever. In this respect, the dynamic roles assumed by the major parts of emerging architecture, such as the FSB and the IMF, could pave the way for more radical and evolutionary reforms, which, in the context of an international treaty, could provide effective solutions to the critical challenges international finance continues to raise.

\section{CAN SOFT-LAW FInANCIAL GovernanCE MEET THE CHALlENGES? LESSONS FROM THE GFC}

This Part of the Article will provide a concise analysis of the effectiveness of soft-law structures underpinning global financial governance. In particular, based on lessons learnt in the course of the GFC, it will ascertain whether present arrangements would be sufficient to avert or manage a global crisis of similar magnitude in the future.

\section{A. Overview}

TRNs and soft law have been hailed as important mechanisms to resolve the regulatory coordination and enforcement challenges posed by globalization in a number of areas ranging from governance of biogenetic research to financial regulation. TRN theory has its origins in a "soft power" view of international relations, which was pioneered by leading

and standards is available at http://www.financialstabilityboard.org/list/fsb_publications/tid_72/ index.htm.

99. Arner \& Taylor, supra note 79, at 488. 
liberal political theorists Robert Keohane and Joseph Nye. ${ }^{100}$ Their analysis was reconceptualized and applied in a number of areas, where international cooperation was of essence, by Anne Marie Slaughter and other international relations scholars. They have proposed a "soft form" of international cooperation through TRNs as an effective solution to global problems. Slaughter and others have conceived trans-governmental networks that, apart from regulatory networks, legislators, judges, and enforcement officials, also include "cooperative arrangements across borders" that "seek to respond to global issues."101

TRNs and soft law present, according to their proponents, two distinct advantages. They lower the cost of contracting ${ }^{102}$ and entail reduced loss of sovereignty, as they are less restrictive and easier to defect than a (hard law) international treaty. ${ }^{103}$ TRNs are also assumed to be a better mechanism to resolve, inter alia, cross-border coordination and enforcement conundrums, especially where issues of sovereignty and national interest protection are of paramount concern. Due to their organizational and legal flexibility, informal transnational networks are thought to be better placed to produce effective rules and standards for the global marketplace and to be more effective implementation channels than hard law structures.

On the other hand, the public-private and national-international nature of the economic activities associated with the operation of global financial markets often presents intractable challenges and dilemmas.

100. See generally Robert O. KeOHANe \& Joseph Nye, Power AND InTERdePendence: WORLD POLITICS IN TRANSITION (3d ed. 2001) (noting especially chapter ten and Part VI); Robert O. Keohane \& Joseph S. Nye, Transgovernmental Relations and International Organizations, 27 WORLD POL. 39, 39-62 (1974).

101. AnNe Marie Slaughter, A New World Order 12-14 (2004). In Slaughter's view, TRNs facilitate coordination and provision of solutions to global problems, but they presuppose a much softer approach to states as international actors and weaker sovereignty, where disaggregated state actors delegate responsibility "to a limited number of supranational government officials" who produce standards of best and commonly agreed solutions to global problems. Id. at 263; see also Kal Raustiala, The Architecture of International Cooperation: Transgovernmental Networks and the Future of International Law, 43 VA. J. INT'L L. 1, 1-92 (2002). Raustiala has linked transgovernmental networks to international liberalism. The TRN participants cooperate in so many ways that transcend sovereignty as to lead Raustiala (and Slaughter) to talk about "disaggregated sovereignty." Id. at 17-26; see also DAvid Singer, Regulating CAPITAL: SETTing STANDARDS For THE INTERNATIONAL FINANCIAL SYSTEM (2007) (offering thorough analysis, in the global financial governance context, of the complex way TRNs operated in the pre-GFC period).

102. Kenneth W. Abbott \& Duncan Snidal, Hard and Soft Law in International Governance, 54 INT'L ORG. 421 (2000).

103. See David Epstein \& Sharyn O'Halloran, Sovereignty and Delegation in International Organizations, 71 LAW \& CONTEMP. PROBS. 77 (2008). For the cost advantages of soft law, see Charles Lipson, Why Are Some International Agreements Informal?, 45 INT'L ORG. 495 (1991); see also Christine Chinkin, The Challenge of Soft Law: Development and Change in International Law, 38 INT'L \& COMP. L.Q. 850-66 (2008). 
Yet, as explained in the previous section, while TRNs are at the heart of global financial governance, these and IFSs are not based on any form of legally binding treaties.

\section{B. Shortcomings in Regulatory Coordination}

The view that TRNs are the solution to the regulatory challenges facing financial markets is not universally accepted. Strong voices have highlighted the multitude of weaknesses associated with the operation of TRNs as global financial regulators. First, a national regulator's principal concern is furthering not global policy objectives but the protection and advancement of the national industry's interests. There is no evidence of the famed dual duty of regulators within TRNs to both domestic and global interests. ${ }^{104}$ But even if there was evidence of such duty, they would still not be entirely impartial actors dedicated to the protection of global public goods such as financial stability. ${ }^{105}$ This finding should have been enough to place TRNs under a different light because every rule or standard proposed by TRNs, at least in the realm of international finance, is bound to have distributional consequences that might affect domestic interests and, above all, domestic financial stability and fiscal outlay.

International regulatory cooperation often involves significant conflicts over the distributive consequences of new standards because the costs and benefits of alternative proposals fall on different states. As developed countries dominate the TRNs, it is not surprising, although inequitable, that these conflicts are resolved in favor of the industries dominated by TRN members, even where this is at the expense of better regulatory outcomes. The most significant distribution concerns are raised by capital market's disclosure, market integrity rules and cross-border crisis management and bank resolution operations. The latter became rather common during the GFC. Even regarding the regulation of systemic risk, approaches may differ according to national economic interest and the desire to protect key economic sectors or the domestic financial services

104. On the assumption that such a duty exists, see Anne-Marie Slaughter, Disaggregated Sovereignty: Towards the Public Accountability of Global Government Networks, 39 Gov'T \& OPPOSITION 159, 163 (2004).

105. E.g., Pierre-Hugues Verdier, Transnational Regulatory Networks and Their Limits, 34 YALE J. INT'L L. 162 (2009) ("The impact of domestic pressures on regulatory networks is most dramatically illustrated by instances of direct political intervention. The Basel II negotiations provide a vivid example: it is perfectly clear that Chancellor Schroeder would not have permitted German banking regulators to agree to rules that would harm SMEs, even if they had thought the policy would improve global financial stability.”). 
industry. ${ }^{106}$ For instance, some countries may prove net exporters of risk because of the (high risk) nature of products sold by national institutions, the business practices they follow (for example, excessive leverage, relaxed credit controls), or both, while maintaining a cross-border presence. In these instances, in the absence of a predetermined legally binding framework, regulators have very little incentive to cooperate and adopt more stringent regulatory standards or, for instance, take Prompt Corrective Action (PCA). Similarly, some smaller, capital-poor countries may have little other means than weak regulations to attract capital. Without a better alternative for attracting income from financial business, they may feel that maintaining weaker standards gives them a competitive edge and benefits that exceed the risk of fraud or institutional failure. A classic example of this behavior was, of course, Iceland. ${ }^{107}$

A particular concern is the effect that the endorsement of a particular standard will have on the competitiveness of its relevant markets. ${ }^{108}$ Some regulators may find stringent rules and regulations an effective means of attracting firms by allowing them to signal their commitment to a sound regulatory system. Meanwhile, other regulators may find it more appealing to adopt lower regulatory standards to attract small financial firms and investment managers seeking to avoid high regulatory costs. In addition, while some regulatory challenges are resolved by TRNs in ways that are beneficial to all states, many do not lend themselves to uncontroversial technical solutions. On the contrary, most of the adopted standards normally favor the markets or industries of developed countries participating in the TRNs. A characteristic example is Basel II, which, had it been fully implemented, would have adversely affected credit flows to the developing world. First, there were problems with the implementation of Basel II by the less technically advanced financial institutions in emerging market economies. Due to lack of resources and

106. Stavros Gadinis, The Politics of Competition in International Financial Regulation, 49 HARV. INT'L L.J. 447 (2008).

107. See David Carey, Iceland: The Financial and Economic Crisis (OECD, Econ. Dep't, Working Paper No. 725, 2009), available at http://search.oecd.org/officialdocuments/ displaydocumentpdf/?doclanguage $=$ en\&cote $=e c o / w k p(2009) 66$; THORSTEN BECK ET AL., BAILING out the BANKS: RECONCILING STABILITY AND COMPETITION-AN ANALYSIS OF STATESUPPORTED SCHEMES FOR FINANCIAL InSTITUTIONS (2010), available at http://www.cepr.org/ pubs/other/Bailing_out_the_banks.pdf.

108. Robert Bailey, Basel II and Development Countries: Understanding the Implications 34 35, 38-39 (London Sch. Econ., Dev. Studies Inst., Working Paper No. 05-71, 2005), available at $\mathrm{http} / /$ www2.lse.ac.uk/internationalDevelopment/pdf/WP/WP71.pdf; see also Stephany GriffithJones \& Stephen Spratt, The New Basle Capital Accord and Developing Countries: Issues, Implications and Policy Proposals (World Inst. for Dev. Econs. Res., Discussion Paper No. 2002/36, 2002), available at $\mathrm{http} / /$ www.wider.unu.edu/publications/working-papers/discussion-papers/2002/en_GB/ dp2002-36/. 
technical sophistication, these were expected to adhere to the standardized approach of Pillar 1, which required a higher capital cushion and thus would raise the costs of developing country banks distorting international competition. ${ }^{109}$ Second, developing country corporations and other entities naturally have lower credit ratings, which would attract, under Basel II, higher capital charges, reducing credit flows to those economies. ${ }^{110}$

TRNs are institutionally ill-equipped to resolve conflicts that entail distributional consequences. ${ }^{111}$ This argument is evidenced beyond any reasonable doubt by the failure to take coordinated rescue and resolution action as regards cross-border financial groups, in the absence of a binding framework for international cooperation and fiscal burden sharing. In order to resolve distributive conflicts, international negotiations must involve concessions and tradeoffs across areas of national interest and, in some cases, threats and other manifestations of power. These tasks are not normally entrusted to regulatory agencies but are exercised by government bodies, which will essentially determine the concessions or threat of sanctions. Accordingly, TRNs are neither as apolitical as they are supposed to be, nor can they be effective monitors without exercise of some sort of sovereign power by the governments of participating states.

Although emerging economies may well be affected by international financial rules, wealthier, developed countries generally have more at stake in complex financial rule making. ${ }^{112}$ For example, some countries may have a relatively small or concentrated domestic investor base, and therefore they may have less at stake or even less interest in developing sophisticated disclosure or investor protection regimes. Thus, while TRN theory has assumed relatively seamless coordination among securities regulators, this is hardly the case. On the contrary, implementation is often the result of the threat of sanctions. ${ }^{113}$

109. Bailey, supra note 108.

110. Griffith-Jones \& Spratt, supra note 108.

111. Verdier, supra note 105 , at 115.

112. Id. at 163 ("In such cases, the resulting standards may be globally efficient, but powerful states will enjoy a disproportionate share of the benefits. This was also arguably the case when the United States and the United Kingdom maneuvered to secure adoption of the Basel I. While the higher capital levels mandated by Basel I likely improved global financial stability, the Accord also allowed the two sponsors to maintain their competitive position. ...").

113. Id. ("The presence of distributive problems also creates opportunities for powerful states to secure their preferred outcome through incentives and threats, as illustrated by the imposition of money laundering and securities fraud rules on OFCs. [Although OFCs strongly preferred lax regulation their] co-operation was secured through threats of sanctions and loss of access to the markets on which their financial industry depends. In such cases, the resulting standards may be globally efficient, but powerful states will enjoy a disproportionate share of the benefits."). 
International standard setters do not always provide clear or effective guidance for emerging challenges or risks. Their pre-GFC standards, especially the Basel capital adequacy framework, proved woefully inadequate in many ways. This is explained in the next section, including a total failure to appreciate the inadequacy of CRAs' models and their glaringly apparent conflicts of interest. Yet, lack of accountability structures has meant that the failures of Basel I and, especially, Basel II had no impact on the standing of BCBS.

\section{All Is Not Well with Private Sector Input}

Some of the aforementioned TRN failures should, in part, be attributed to the quasi-regulatory role assigned to private actors. The input of private actors is sometimes based on rather imperfect science and is motivated by private interests. ${ }^{114}$ Namely, TRNs' excessive reliance on private actors' knowledge and expertise is often misplaced. ${ }^{115}$ For example, the strong push by industry to base capital adequacy standards on a risk modeling approach also translated into relentless equity reduction practices in favor of debt, which of course led to over-leveraged and severely under-capitalized banks. ${ }^{116}$ Uncritical endorsement of private sector expertise and policy preferences also fostered self-regulation in derivatives markets, which proved inadequate to prevent a large-scale financial crisis.

The trouble with excessive reliance on private sector input is not just that private actors try to promote their own agenda, a pretty legitimate goal on their part. An even bigger problem is that such uncritical endorsement incorrectly assumes that private actors' knowledge is complete, while in fact it is very fragmentary, often steeped in ignorance, ${ }^{117}$ and unheeding of true market conditions. ${ }^{118}$ These shortcomings are due

114. Frank Partnoy, How and Why Credit Rating Agencies Are Not Like Other Gatekeepers, in FinANCIAL GateKeEPERS: CAN They PROTECT InVESTORS? (Yasuyuki Fuchita \& Robert E. Litan eds., 2006); Steven L. Schwarcz, Private Ordering of Public Markets: The Rating Agency Paradox, 2002 U. ILL. L. REV. 1 (2002).

115. Martin Hellwig, Capital Regulation After the Crisis: Business as Usual?, CESIFO DICE REP., July 2010, at 41.

116. See Basel Committee on Banking Supervision, The Basel Committee's Response TO THE FINANCIAL CRISIS: REPORT TO THE G20 4 (2010); Hellwig, supra note 115, at 2-4.

117. "Blankfein ... argued that the real problem was that people had not realised they were taking excessive risk and that in that case a properly constructed leverage ratio may have been an appropriate back-stop against a possible mistake in risk assessment.” EUROFI FINANCIAL FORUM 2010, CONFERENCE REPORT: Optimizing EU FINANCIAL REFORMS FOR ACHIEVING RESILIENCE, GROWTH, AND COMPETITIVENESS: WHAT PRIORITIES? WHAT ROADMAPS? 57 (2010), available at http://www.eurofi.net/wp-content/uploads/2012/11/Eurofi-Brussels-2010-conference-report.pdf (summarizing the comments of Lloyd C. Blankfein). Blankfein is, of course, the chairman and chief executive officer of the world's best-known investment bank, Goldman Sachs.

118. Julia Black has noted: 
to two factors. First, private actors, deeply entrenched themselves in the constantly changing winds of the markets, do not have enough incentives to gather diverse pieces of data that would provide a more complete picture of the markets, when such data covers areas beyond their immediate business needs. Second, market conditions often differ from what is expected in equilibrium. However, disequilibrium conditions are as much the product of market actors' own behavior as of anything else.

Private actors' inadvertent myopia in disequilibrium is witnessed beyond reasonable doubt by their frequent inability to either identify an asset bubble or react to it. Normally, this is due to two factors. First, private actors' cognitive biases and socio-psychological pressures distort valuations and trigger strategic trade behavior (herding), which in turn intensifies disequilibrium conditions. ${ }^{119}$ Second, the actions of private actors themselves create the market conditions under scrutiny, a phenomenon known as reflexivity. ${ }^{120}$ In those cases, requesting private actors to accurately observe the impact of their own actions and intentions in relaying their analysis of market conditions to their regulatory masters

There is a growing recognition that regulators do not have the resources necessary by way of information, tools and technologies, organisational capacities, leverage, and, at the international level in particular, legitimacy and authority to perform regulation effectively. However, this is also matched by a recognition that firms and markets do not possess these resources either.

Julia Black, Restructuring Global and EU Financial Regulation: Capacities, Coordination and Learning 16 (London Sch. Econ., Law, Soc'y \& Econ., Working Paper No. 18/2010, 2010), available at http://www.lse.ac.uk/collections/law/wps/WPS2010-18_Black.pdf.

119. See Emilios Avgouleas, A New Framework for the Global Regulation of Short Sales, Why Prohibition is Inefficient and Disclosure Insufficient, 15(2) STAN. J.L. BuS. \& FIN. 376, 376-425 (2010) [hereinafter Avgouleas, New Framework]; David Hirschliefer, Investor Psychology and Asset Pricing, 56 J. Fin. 1533, 1533-97 (2001); Emilios Avgouleas, Cognitive Biases and Investor Protection Regulation: An Evolutionary Approach (May 2006) [hereinafter Avougleas, Cognitive Biases] (unpublished manuscript), available at $\mathrm{http} / / /$ papers.ssrn.com/sol3/papers.cfm?abstract_id=1133214.

120. The legendary financier George Soros has offered a good analysis of reflexivity in the context of financial markets:

Both philosophy and natural science have gone to great lengths to separate events from the observations which relate to them. Events are facts and observations are true or false, depending on whether or not they correspond to the facts... [As a result of applying this view to financial markets] the [prevailing] interpretation of the way financial markets operate is severely distorted... Thinking participants cannot act on the basis of knowledge. Knowledge presupposes facts which occur independently of the statements which refer to them; but being a participant implies that one's decisions influence the outcome. Therefore, the situation participants have to deal with does not consist of facts independently given but facts which will be shaped by the decision of the participants. There is an active relationship between thinking and reality. . . Reflexivity is, in effect, a two-way feedback mechanism in which reality helps shape the participants' thinking and the participants' thinking helps shape reality. ...

George Soros, Chairman, Soros Fund Mgmt., Remarks at Mass. Inst. of Tech.: Theory of Reflexivity (Apr. 26, 1994). 
and partners is stretching perceptions of private actors' cognitive ability beyond the limits of credulity.

For example, I have argued elsewhere that private sector inability (or unwillingness) to close regulators' knowledge gap meant that the financial revolution was very little understood and much misunderstood by policymakers and supervisors, stretching their cognitive capacity to a breaking point. ${ }^{121}$ Therefore, TRNs' information advantages due to wider private sector participation may not be overestimated, and the global regulatory community should consider establishing more formal structures when it comes to identifying risks, especially those risks occasionally arising from innovative financial techniques and instruments.

\section{Monitoring and Enforcement of International Financial Standards}

The success of soft-law standards is dependent in large part on the ability of regulators and market participants to identify defections and deviations from what has been agreed. Monitoring is thus a necessary means to facilitate compliance. Only through timely detection of defection can the disciplining mechanism of reputation loss work effectively. Nevertheless, the architecture supporting financial sector monitoring is, in many regards, quite weak. For one, the surveillance of compliance with international regulatory agreements is available for a relatively finite range of instruments. Regulatory commitments made by political institutions, or through communiqués promulgated by the " $G$ " groupings in the wake of their summits, have often been lightly monitored. Similarly, only basic legislative standards promulgated by TRNs are incorporated into FSAP surveys.

Even where rules are incorporated into financial sector assessments, monitoring of compliance may remain weak. FSAP participation was, for example, entirely voluntary for non-IMF and non-World Bank borrowers. Also, data provided to international standard-setting bodies is normally self-reported by national authorities and is subject to little verification. FSAP has provided a weak and defective monitoring mechanism.

Accordingly, even when they are adopted in a timely manner, TRN standards still frequently face enforcement problems, as states are tempted to defect from the cooperative framework-especially when they are under pressure from powerful domestic constituencies. ${ }^{122}$ Even IOSCO's

121. See Avgouleas, supra note 3, at ch. 3; see also Black, supra note 118.

122. Arguably, it is very hard to see national regulators who have voted in favor of countercyclical capital regulations ("the counter-cyclical buffer") in Basel to restrict bank lending because the IMF or the BIS tell them that it feeds into an emerging asset bubble, in the absence of formal and legally binding domestic legislation. The uproar from banks and businesses could be so strong as to force to submission even the most powerful and opinionated of regulators. See BASEL COMM. ON 
record is less solid than it sounds, and most of the convergence has been achieved in areas in which major markets had a strong interest. ${ }^{123}$ Similarly, in the field of fraud and money laundering, the biggest jurisdictions seem to have used FATF to impose their will on smaller jurisdictions hosting tax havens in order to protect their interests. Rules are also unevenly enforced. ${ }^{124}$ Therefore, the informal and nonbinding nature of the rules adopted by TRNs and the incapacity to monitor or enforce them limit their effectiveness in circumstances where states have incentives to defect. ${ }^{125}$ TRNs in that case are powerless to react without the intervention of governments and the threat of bilateral or multilateral sanctions. Incentives to defect do not come bigger than in the context of a major international financial crisis, where the resolution of cross-border financial institutions may entail massive fiscal costs for the participating regulators.

\section{E. The Issue of Legitimacy}

Another big concern associated with TRNs is their (lack of) legitimacy, ${ }^{126}$ and the identification of actions that could be taken to remedy

BANKING SuPERVISION, BASEl III: A Global Regulatory Framework FOR MORE RESILIENT BANKS AND BANKING SYSTEMS 57 (2010), available at www.bis.org/publ/bcbs189.pdf.

123. Goodhart observes: "Thus Basel I, the Accord on Capital Regulation in 1988, was propelled by concern that many of the major international banks, especially in the USA, would have been made insolvent, under a mark-to-market accounting procedure, by the MAB (Mexican, Argentina, Brazil) default crisis of 1982. Congress wanted to impose higher capital regulations on US banks, but was deterred by the Level Playing Field argument that any unilateral move would just shift business to foreign, especially to Japanese, banks." Hence the appeal to the BCBS. Charles Goodhart, How Should We Regulate Bank Capital and Financial Products? What Role for "Living Wills"?, in THE FUTURE OF FINANCE: THE LSE REPORT 165-86 (Adair Turner et al. eds., 2010); see also Gadinis, supra note 106, at 449-54.

124. For example, compliance with TRN standards can be enforced much more effectively in the case of countries borrowing from the IMF and the World Bank, which, via the conditionality attached to such loans, can be forced to commit to or implement international standards promulgated by organizations like the BCBS, IAIS, and IOSCO.

125. For example, the 1988 Basel I Accord gradually unraveled as national regulators adopted self-serving exceptions and interpretations, because "the Committee had little effective leverage to enforce its rules." Verdier, supra note 105, at 163.

126. For an overview of the legitimacy deficit in the specific context of global financial governance, see Geoffrey R.D. Underhill \& Xiaoke Zhang, Norms, Legitimacy, and Global Financial Governance, (ESRC World Econ. \& Fin. Programme, Working Paper No. WEF 0013, 2006), available at $\mathrm{http}: / /$ papers.ssrn.com/sol3/papers.cfm?abstract_id=941389. On the inadequacy of standards of legitimacy underpinning global governance institutions, see Daniel Bodansky, The Legitimacy of International Governance: A Coming Challenge for International Environmental Law?, 93 AM. J. INT'L L. 596, 596-624 (1999). On the issue of legitimacy in international law, see Rudiger Wolfrum, Legitimacy in International Law from a Legal Perspective: Some Introductory Considerations, in LEGITIMACY IN INTERNATIONAL LAW (Rudiger Wolfrum \& Volker Robens eds., 2008). A very insightful earlier work is THOMAS Franck, THE POWER OF LEgitimaCy AMONG NATIONS (1990). 
this defect. ${ }^{127}$ Two leading liberal scholars have defined legitimacy of global governance institutions as follows ${ }^{128}$ :

"Legitimacy" has both a normative and a sociological meaning. To say that an institution is legitimate in the normative sense is to assert that it has the right to rule - where ruling includes promulgating rules and attempting to secure compliance with them by attaching costs to noncompliance and/or benefits to compliance. An institution is legitimate in the sociological sense when it is widely believed to have the right to rule.

The "normative view of legitimacy" essentially asks whether any international organization or body was established by state actors or organizations recognized under international law, which, in turn, had the competence under national or international law to engage in the action in question. Therefore, the perception of legitimacy ("believed to have the right to rule") is the most important. In fact, the thorniest legitimacy question attached to TRNs in the field of global finance is not so much lack of political controls ${ }^{129}$ because heads of state and ministers participate in the G-20 and treasury departments are represented in BCBS. It is more an issue of lack of accountability mechanisms because their softlaw nature does not allow the establishment of accountability structures similar to those in place for the United Nations or the WTO. Moreover, building global governance organizations merely on the basis of participating states' consensus, giving them the right to rule, is not sufficient. Even if a relevant body was exclusively based on the consent of democratic states, and thus democratic accountability structures were ensured, the main functions of this body would be discharged by a bureaucracy, which would enjoy a wide margin of discretion whether its decisions were made at the national or international level. ${ }^{130}$ Thus, this body would not meet the second of the above tests-widely believed to have the right to rule. To meet the second test, global governance institutions should provide benefits that cannot be provided by states. ${ }^{131}$ In addition, global

127. For a number of commentators, the biggest legitimacy concern associated with TRNs is the so-called democratic deficit, normally translated as the absence of serious involvement by national governments with TRNs. For an overview of the legitimacy challenge, see Julia Black Legitimacy, Accountability and Polycentric Regulation: Dilemmas, Trilemmas and Organisational Response, in NON-STATE ACTORS AS STANDARD SETTERS 241-69 (Anne Peters et al. eds., 2009).

128. Allen Buchanan \& Robert O. Keohane, The Legitimacy of Global Governance Institutions, in LEGITIMACY IN INTERNATIONAL LAW ch. 2, 25 (Rudiger Wolfrum \& Volker Roben eds., 2008).

129. Cf. Geoffrey Underhill, Keeping Governments Out of Politics: Transnational Securities Markets, Regulatory Cooperation, and Political Legitimacy, 21 REV. INT'L STUD., 251, 251-78 (1995).

130. Buchanan \& Keohane, supra note 128 , at 39-41.

131. Id. at $40-42$. 
governance institutions need to be based on the incorporation of a clear set of shared values, but TRN objectives often lack clarity. Finally, being a collection of experts and bureaucrats, TRN legitimacy could be strengthened through the establishment of some form of indirect accountability to the global polity, ${ }^{132}$ but formal institutions have proved more successful at achieving that. TRNs producing IFSs fall far short of satisfying the second test of legitimacy for a host of other reasons. As we have already seen, many international standard-setters, like the BCBS, "are exclusive in their membership or dominated by a narrow band of (usually rich) countries." ${ }^{.133}$ Even TRNs with very wide and representative membership like IOSCO may have tight knit cores in terms of policymaking, such as IOSCO's Technical Committee.

Regulatory groupthink, mono-dimensionality, and domination by larger and more sophisticated members, which represent bigger constituencies and often possess superior expertise, create serious policy implications for TRNs. First, they are likely to produce standards that favor members at the expense of nonmembers. In fact, distributive issues are much more likely to be decided in favor of those with direct policy input. Second, TRNs are very likely to refrain from adopting standards that do not favor their stronger members. For some commentators, this inevitable dominance of TRNs by the more advanced economies, until recently the United States and a few E.U. countries, has led to a new form of extraterritorial application of their laws and regulatory traditions. ${ }^{134}$

On the other hand, a number of respected scholars argue that, in recent years, open and extensive consultations held by TRNs before the promulgation of new standards have largely resolved the issue of legitimacy. ${ }^{135}$ Moreover, G-20, FSB, and BCBS member countries (following membership enlargement) do represent the world's biggest economies, and, being hosts to the largest financial services industries, they have

132. See generally David Held, Law of States, Law of Peoples: Three Models of Sovereignty, 8 LEGAL THEORY 1, 1-44 (2002); Robert O. Keohane, Global Governance and Democratic Accountability, Miliband Lectures at the London School of Economics (2002). In the context of International Finance TRNs, see Claire R. Kelly, Financial Crises and Civil Society (Aug. 4, 2010) (unpublished manuscript), available at http://works.bepress.com/cgi/viewcontent.cgi?article=1015\&context= claire_kelly.

133. Chris Brummer, How International Financial Law Works (And How It Doesn't) (Sept. 6, 2010) (unpublished manuscript), available at http://cms1.runtime.com/null/Brummer, $+\mathrm{C}+-$ + Fall $+10+$ WS exclusive $=$ filemgr.download\&file_id $=541218 \&$ showthumb $=0$ (earlier version of Brummer, supra note 3).

134. See Rolf H. Weber, Multilayered Governance in International Financial Regulation and Supervision, 13 J. INT'L ECON. L. 683-704, 695 (2010).

135. Michael S. Barr \& Geoffrey P. Miller, Global Administrative Law: The View from Basel, 17 EuR. J. INT’L L. 15, 16 (2006); see also Daniel C. Esty, Good Governance at the Supranational Scale: Globalizing Administrative Law, 115 YALE L.J. 1490 (2006). 
more experience and a higher level of expertise in dealing with the most important issues of global finance, such as large and complex financial institutions and markets for sophisticated financial instruments.

\section{F. Lessons from the GFC \\ 1. Introductory Remarks}

Soft law and TRNs are very important and useful components of global governance, especially in areas where a strong pooling of sovereignty would be regarded as intolerable by states. They also have several shortcomings, as explained above. In many ways this form of governance for international finance proved largely ineffective. On the other hand, criticism of TRNs should not be generalized and care should be taken not to diminish the valuable role in information sharing and promotion, through soft law, of cooperative forms of governance in a number of other spheres of transnational interaction.

Even notable TRN theorists have pointed out that the soft-law structures proved to be ineffective, or at best "marginally helpful," in managing the GFC. ${ }^{136}$ First, Basel capital adequacy standards are widely assumed to have seriously contributed both to the buildup and the severity of the crisis. Second, the lack of formal structures for cross-border coordination of crisis management and failing bank resolution generated gigantic amounts of confusion and uncertainty resulting in a generalized collapse of confidence in the markets, especially after the messy collapse and winding up of Lehman Brothers. Finally, the standards themselves were in many instances flawed, and, as explained below, they seem to have contributed to, instead of prevented, the GFC. ${ }^{137}$

\section{The Flaws of the Basel Capital Framework}

It has been accurately and consistently argued that the focus of $\mathrm{Ba}-$ sel standards on individual institutions' financial standing (micro-

136. David Zaring, International Institutional Performance in Crisis, 10 CHI. J. INT'L L. 475, 477-85 (2010). Also, Giovanoli, a former BIS General Counsel, has noted: "Looking back, it may seem astonishing that the global financial crisis of 2008 and 2009 . . . happened at the international level despite the existence of a comprehensive corpus of international financial standards (IFSs). ... . Did the international financial architecture turn out to be a product of "fair weather architecture"? ... To say the least, the existing IFS, despite their wide scope and sophistication did not prevent the outbreak of the current crisis." Mario Giovanoli, The Reform of the International Financial Architecture After the Global Crisis, 42 N.Y.U. J. INT'L L. \& POL. 81, 83-85 (2009).

137. See Avgouleas, supra note 3 , at ch. 3. 
prudential regulation) was flawed. ${ }^{138}$ Basel capital regulations also proved to be problematic in many other areas, mostly because of four factors. First, capital standards were very procyclical. Second, the capital standards tended also to foster regulatory arbitrage. Third, the Basel I and Basel II frameworks totally neglected liquidity risks in the banking sector. Fourth, the provision of incentives to adhere to the risk-modeling approach encouraged leverage, allowing banks to assume large amounts of short-term debt.

Basel capital requirements also showed a poor appreciation of the importance and cost of strong equity cushions. This was due to regulatory arbitrage, whereby riskier assets attracting a higher capital cushion were securitized and taken off the balance sheet, as well as poor capture of actual risks by the models used, especially by Basel II, which were based on industry developed risk management models, especially the socalled Value at Risk (VaR). VaR had serious shortcomings for a number of reasons and probably constituted a flawed way to capture asset riskiness. ${ }^{139}$ First, the model was not based on sound empirical grounds. Its timeline was short and thus, in certain asset markets such as housing, where prices had been rising constantly for twenty years, it systematically underestimated the risk of default. ${ }^{140}$ Second, it failed to capture correlations among assets. ${ }^{141}$ Third, it did not distinguish between risk and uncertainty. As the model assumed normal distributions of events, it could not capture tail risk, namely, rare extreme loss events-so-called fat tails or black swans - which, in fact, may not be modelable. ${ }^{142}$ More-

\footnotetext{
138. MARKuS BRUNNERMEIER ET AL., THE FundAMENTAL PRINCIPLES OF FinANCIAL REgulation: GENEVA REPORTS ON WORLD ECON. 11 6-10 (2009), available at http://www.princeton.edu/ markus/research/papers/Geneva11.pdf.

139. For an analytical discussion, see AVGOULEAS, supra note 3, at 242-45.

140. This statement by former U.S. Federal Reserve Chairman Alan Greenspan is characteristic:

It was the failure to properly price such assets that precipitated the crisis. . . The modern risk management paradigm held sway for decades. The whole intellectual edifice, however, collapsed in the summer of last year [2007] because the data inputted into the risk management models generally covered only the past two decades, a period of euphoria. Had instead the models been fitted more appropriately to historic periods of stress, capital requirements would have been much higher and the financial world would be in far better shape today....

Financial Crisis and the Role of Federal Regulators: Hearing Before the H. Comm. on Gov't \& Oversight Reform, 110th Cong. (2008) (testimony of Alan Greenspan, Former Chairman, Fed. Reserve).

141. Basel Comm. on Banking Supervision, Consultative Document Strengthening THE RESILIENCE OF THE BANKING SECTOR 37-8 (2009), available at www.bis.org/publ/bcbs164.pdf. "The Committee, based on its empirical work, found evidence that asset value correlations were at least $25 \%$ higher for financial firms than for non-financial firms." Id. at 38; $c$. Hellwig, supra note 115 , at 7 .
}

142. It has been accurately observed that 
over, what risk models could not capture is the very risk that regulation should be alert to guard against. ${ }^{143}$ Fourth, it was very procyclical and thus patently unsuitable for use in regulatory models that tried to protect financial institutions and the financial system from, inter alia, the risk of economic downturns, which is inevitable in all economic cycles. Fifth, it focused on defaults, which are less frequent events, and not on the much more frequent asset price changes, which may prove as dangerous for banks' financial health. ${ }^{144}$ Sixth, it failed to capture endogenous risk, namely, the risk emanating from the behavior of actors within the system, as a response to an exogenous or endogenous development, which could lead to contagion and domino phenomena. A domino or cascade event can force even perfectly hedged and soundly managed financial institutions to fail and is, arguably, the biggest risk for the banking system. VaR assumed independence in institutional actions and did not measure the impact of each institution's actions on the behavior of other institutions and the market. Namely, it did not capture self-reinforcing cycles.

[the view that] past distribution patterns carry robust inferences for the probability of future patterns is methodologically insecure. It involves applying to the world of social and economic relationships a technique drawn from the world of physics, in which a random sample of a definitively existing universe of possible events is used to determine the probability characteristics, which govern future random samples. But it is unclear whether this analogy is valid when applied to economic and social relationships, or whether instead, we need to recognise that we are dealing not with mathematically modellable risk, but with inherent "Knightian uncertainty."

Fin. Servs. Auth., A Regulatory Response to the Global Banking Crisis 21 (2009) [hereinafter FSA, REGULATORY RESPONSE], available at http://www.fsa.gov.uk/pubs/discussion/ dp09_02.pdf.

143. See Goodhart, supra note 123 , at 165.

[T] he precept that each individual bank's own risk management should be brought up to the level of, and harmonised with ... the (best) practices of the most technically advanced individual banks ... was wrong for two main associated reasons. First, the risk management concerns of individual banks are, and indeed should be, quite different from those of regulators. A banker wants to know what his/her individual risk is under normal circumstances, $99 \%$ of the time. If an extreme shock occurs, it will anyhow be for the authorities to respond. For such normal conditions, the VaR measure is well designed. But it does not handle tail-risk adequately. ... It is the tail risk of such extreme shocks that should worry the regulator.

Id.; see also Jon Danielsson, The Emperor Has No Clothes: Limits to Risk Modelling, 26 J. BANKING \& FIN. 1252, 1252-72 (2002).

144. As Brunnermeier, et al. note:

[D]efaults need not even be necessary to generate contagion. Price changes themselves may be enough. When financial institutions mark their bal- ance sheets to market, changes in prices lead to losses that may be sufficient to transmit the shocks to other institutions even when they do not hold claims against each other. Losses worsen funding liquidity for many financial institutions, forcing them to shed even more assets which further depresses prices and increases losses, and so on.

Brunnermeier, et al., supra note 138, at 14 (emphasis added). 
3. Supervisory Failures, Cross-Border Crisis Management and Resolution "Too-Big-to-Fail" Institutions

\section{a. Supervision of Cross-Border Financial Institutions}

The two IFIs, the IMF and the World Bank, are involved in the current governance framework for global finance in the process of standardsetting and monitoring of compliance. However, they lack any kind of legal standing to act as global financial regulators. On the other hand, TRNs have no supervisory capacity.

Supervision in financial markets is a competence and function, the discharge of which has predominantly been confined within national borders. Also, there has not been a clear distinction between two different functions of regulation: rulemaking and standard-setting on the one hand and supervision on the other-even in the domestic context. ${ }^{145}$ The latter is roughly defined as the day-to-day monitoring of regulated firms' compliance with applicable regulations and imposition of sanctions. This was not regarded as a major failing until the eruption of GFC. The fact that TRNs were not involved in supervision and had no enforcement powers was viewed as an issue of little importance, although certain commentators had either highlighted this absence or advocated the need for the establishment of a global systemic regulator. The lack of any capacity to supervise cross-border institutions and of any clear cooperation in a crisis management (and burden sharing) framework at the international level, which could reconcile home- and host-country interests, became a serious problem during the GFC.

There are good reasons to believe that at least Icelandic authorities (and possibly Irish regulators as well) were particularly permissive regulators, viewing their banks as their national champions. Icelandic banks maintained a widespread geographic distribution of assets rather disproportionate to the size of the country's Gross Domestic Product. But hostcountry authorities had no effective tools for early intervention under the prevailing framework. Early intervention was, however, exactly what was required to avoid placing host-country banking systems under serious threat. ${ }^{146}$

145. See Pan, supra note 86. Perceptive earlier works that drew such a distinction between the two different concepts are Rosa M. Lastra, The Governance Structure for Financial Regulation and Supervision in Europe, 10 ColuM. J. EuR. L. 49 (2003); Cynthia Crawford Lichtenstein, The Fed's New Model of Supervision for "Large Complex Banking Organizations": Coordinated Risk-Based Supervision of Financial Multinationals for International Financial Stability, 18 TRANSNAT'L LAW. 283, 287-88 (2005).

146. See FSA, RegUlatory ReSPONSE, supra note 142, at 16, 56, 154. 
Moreover, where national authorities were being faced with colossal cross-border bank rescue dilemmas and expensive conflicts of interest, MoUs and other soft-law structures could play no meaningful role. Characteristic examples are the acrimonious cross-border treatment of the failure of Icelandic banks and the messy rescue of Fortis, a large European bank with a strong presence in three countries. ${ }^{147}$ Both cases are surprising examples, as they happened within or just outside the borders of the E.U., the region with the highest level of harmonization of national banking laws.

\section{b. Resolution of Cross-Border Financial Institutions}

Arguably, the most important lesson learned from the collapse of Lehman is that, while the business of a banking group is run on an integrated global basis, its corporate structure is highly fragmented and labyrinthine. This is normally the result of regulatory and tax arbitrage or local legal requirements, or it is put in place to evade legal liability spilling over from one corporate entity to the other within the same group. ${ }^{148}$ The Lehman and Fortis cases have highlighted the incompatibility of cross-border group structures with national resolution regimes and insolvency procedures. ${ }^{149}$ This is one of the biggest threats to financial globalization ${ }^{150}$ because it has become obvious that, in the absence of clear

147. See BASEl COMm. ON BANKING SUPERVISION, REPORT AND ReCOMMENDATIONS OF THE CROSS-BORDER BANK RESOLUTION GROUP 10-12 (2009).

148. Richard Herring \& Jacopo Carmassi, The Corporate Structure of International Financial Conglomerates, Complexity and Its Implications for Safety and Soundness, in XFORD HANDBOOK OF BANKING 173-204 (Allen N. Berger, et al. eds., 2010); see also BASEL COMM. ON BANKING SUPERVISION, REPORT AND RECOMMENDATIONS, supra note 147, at 14-16.

149. Stijn Claessens et al., A Safer World Financial System: Improving the RESOLUTION OF SYSTEMIC INSTITUTIONS, GENEVA REPORT ON WORLD ECON. 12 (2010), available at http://personal.vu.nl/d.schoenmaker/Geneva12.pdf.

150. One obvious remedy is, of course, to ring-fence branches and subsidiaries in the host jurisdiction. But as Goodhart, Schoenmaker, and I have argued, it is unlikely that even ring-fenced subsidiaries will survive the reputation contagion of apparent failure, which will cause a retail or wholesale creditor run on the subsidiary resulting, in the beginning, severe funding problems and, eventually, forced bankruptcy. See E. Avgouleas, C. Goodhart \& D. Schoenmaker, Bank Resolution Plans as a Catalyst for Global Financial Reform, 6 J. Fin. STABILITY (2011). Also, it has been observed that ring-fencing may prove costly and complicate, instead of simplify, cross-border group resolutions. The segregation of intra-group internal funding and liquidity flows will create operating inefficiencies and may amplify rather than resolve the problem of cross-border bank failures and even impose extra costs on a host country's economy. See Eugenio Cerutti et al., Bankers Without Borders? Implications of Ring-Fencing for European Cross-Border Banks (Int'l Monetary Fund, Working Paper No. 10/247, 2010), available at http://www.imf.org/external/pubs/ft/wp/2010/ wp10247.pdf. 
cross-border supervisory structures and a single insolvency regime, the operation of SIFIs on a cross-border basis entails serious dangers. ${ }^{151}$

The European Union has moved toward adoption of a harmonized approach to bank resolution and insolvency, ${ }^{152}$ as the only realistic alternative to the coordination chaos and risk of systemic collapse observed during the Lehman failure and the Fortis rescue. On the other hand, the FSB has published a document containing key attributes that all bank insolvency regimes ought to present and advocating a mutual recognition approach to cross-border resolutions. However, the mutual recognition approach that the FSB champions ${ }^{153}$ and ensuing uncertainty over the quality of local regimes due to absence of binding harmonization pacts, means that several of the existing obstacles to cross-border resolution will remain intact.

Another very thorny issue is how to share the burden in the case of rescuing a cross-border bank or other financial institution. Using taxpayers' money in one country to bail out the institutions of another country is an unjust approach and often politically untenable. Thus, in the absence of an international convention (statute) governing the resolution of cross-border financial institutions and financial groups, which would be backed by explicit and legally binding burden-sharing arrangements, progress in this area should be regarded as limited, in spite of the occasional hype.

\section{THE STATE OF REFORM WITH RESPECT TO BANK REGULATION AND SYSTEMIC RISK}

In the previous Part, I gave a brief overview of structural reforms taking place at the level of international financial regulation, where softlaw bodies are being fit into a tighter new architecture that has at its center the FBS and, at its apex, the G-20. Structural reforms as a response to the GFC have also taken place in most Western economies. The U.S. Dodd-Frank Act has established a new macro-prudential regulator, the Financial Stability Oversight Council (FSOC). The structure of financial

151. JACOPO CARMASSI ET AL., OVERCOMING TOO Big TO FAIL: A REgUlATORY FRAMEWORK to Limit Moral Hazard and Free Riding in the Financial Sector (2010), available at http://aei.pitt.edu/14484/1/TFR_Bank_Crisis_Resolution.pdf.

152. European COMm'N, Proposal FOR a Directive Establishing a Framework fOR THE RECOVERY AND RESOLUTION OF CREDIT INSTITUTIONS AND INVESTMENT FiRMS AND AMENDING COUNCIL DiRECTIVES 77/91/EEC AND 82/891/EC, DiRECTIVES 2001/24/EC, 2002/47/EC, 2004/25/EC, 2005/56/EC, 2007/36/EC, AND 2011/35/EC, AND REGULATION (EU) No 1093/2010 (2012), available at http://ec.europa.eu/internal_market/bank/docs/crisismanagement/2012_eu_framework/COM_2012_280_en.pdf.

153. Fin. Stability BD., Key Attributes of Effective Resolution Regimes for FINANCIAL INSTITUTIONS (2011), available at http://www.financialstabilityboard.org/publications/ r_111104cc.pdfhttp://www.financialstabilityboard.org/publications/r_111104cc.pdf. 
supervision has radically changed in the European Union as well with the introduction of the European System of Financial Supervisors. Even more wide-ranging have been the reforms to the substantive rules governing the financial sector. The Dodd-Frank Act and the E.U. legislators have brought about sweeping changes as regards the regulation, supervision, and resolution of large banks and other SIFIs, OTC derivatives trading, and ratings production by the Credit Rating Agencies (CRAs). In addition, the BCBS has produced a radically upgraded capital, liquidity, and leverage regulation. I provide in this Part an analytical discussion of the most important of these reforms. As the new regulations are rather labyrinthine, I provide below brief summaries as an introduction before moving to more detailed analysis.

\section{A. Summary of Reforms in the United States and the European Union}

\section{The U.S. Reforms}

The Dodd-Frank Act (the Act) was enacted on July 9, 2010, after a prolonged period of public and Congressional debate. ${ }^{154}$ The final Act was in many respects the culmination of several political compromises ${ }^{155}$ and has since become the subject of serious criticism from both sides of the increasingly polarized political landscape in the United States. The main goal of the Act is to address the risks that relate to eventual failure of "too-big-to-fail institutions" (SIFIs) and the risks relating to financial innovation and the shadow-banking sector. It also tries to create a strict framework for consumer protection, including the establishment of the Consumer Financial Protection Bureau (CFPB), in order to avoid a repeat of the sub-prime mortgage scandal.

With respect to SIFI regulation, the Act's main innovation is the creation of a number of new regulators and establishment of a new reso-

154. The Dodd-Frank Act is a 2,300-page long document. A number of U.S. law firms have released extensive summaries of, and commentary on, the Act. See, e.g., SKADDEN, ARPS, SLATE, Meagher \& Flom LlP \& AfFiliate, The Dodd-Frank ACt: COMmentary and Insights (2010); Mayer Brown, Understanding the Financial Reform Legislation: The DoddFrank Wall Street Reform and Consumer Protection ACt (2010); Davis Polk, Summary of the Dodd-Frank Wall Street Reform and Consumer Protection Act, Passed By the HOUSE OF REPRESENTATIVES ON JUNE 30, 2010 (2010). For a good analysis of the issues DoddFrank attempts to regulate and the policy and regulatory tools that it employs, see REGULATING Wall Street: The DodD-Frank Act AND the NeW ARChitecture of Global FinANCE (Viral Acharya et al. eds., 2011). An excellent analysis of the various aspects of the Dodd-Frank Act is provided in David Skeel, The New Financial Deal: Understanding the Dodd-Frank ACT AND ITS (UNINTENDED) CONSEQUENCES (2011).

155. For the political battles surrounding the enactment of the Dodd-Frank Act and its underling political goals, see David Skeel, The New Financial Deal: Understanding the Dodd-Frank Act and its (Unintended) Consequences 1-4 (Univ. of Penn., Inst. for Law \& Econ., Research Paper No. 10-21, 2010), available at http://papers.ssrn.com/sol3/papers.cfm?abstract_id=1690979. 
lution regime that will be dedicated to systemically important institutions regardless of whether they hold a bank license or not. The Act also curbs, through the so-called Volcker Rule, the ability of regulated banks to engage in the most speculative forms of investment banking, such as proprietary trading, and reduce their involvement with and exposure to the shadow-banking sector. The Act mandates a framework for the standardization of OTC derivatives contracts introducing on exchange trading and clearing requirements for most classes of such contracts. While the Act is by all accounts a major step forward in the regulation of the U.S. financial services industry, it has been validly criticized on three grounds. First, it does not eradicate the "too-big-to-fail" problem. Second, the cost of compliance is very considerable and, thus, the Act's implementation will likely have an adverse impact on the competitiveness of the U.S. financial services industry. Third, the Act is largely unhelpful when it comes to international regulatory cooperation and is bound to generate strong regime conflicts and obstacles to supervisory coordination through its extraterritorial reach as well as compliance loopholes.

\section{Reform in the European Union}

The European Union's reliance on a supervisory model that was centered on national supervisors proved to be terribly flawed, justifying those who doubted whether a stable financial system, an integrated financial system, and national financial autonomy (so-called financial stability "trilemma") are compatible. ${ }^{156}$ The structures for cooperation, coordination, and consistent application of E.U. law were very weak. They were particularly ineffective when it came to managing the challenges arising from failing financial institutions operating cross-border both within Europe and globally. These exhibited strong links of interconnectedness and were major sources of systemic risk for a host of national markets. The failure of those institutions also exposed a marked lack of trust among national supervisors. Even regulators from neighboring E.U. member states, who also had established, via the Lamfalussy Committee of European Banking Supervisors (CEBS), a good understanding with their counterparts, chose, nevertheless, to follow a national approach when it came to dealing with distressed cross-border financial institutions, as in the Icelandic banks' and Fortis' cases. ${ }^{157}$

156. See Dirk Schoenmaker, The Financial Trilemma, (Duisenberg Sch. of Fin., Working Paper No. TI 11-019/DSF 7, 2009), available at http://papers.ssrn.com/sol3/papers.cfm?abstract_ id $=1340395$.

157. See AvgOULEAS, supra note 3, at ch. 5. 
In this context, three main problems were identified. First, there was a marked lack of any framework for the monitoring of systemic risk (macro-prudential oversight) in the entire European Union. Second, the loopholes of "home country control" came into sharp focus. The failure of Icelandic banks especially exposed the gaps in cross-border supervision of banking groups in the European Union and the European Economic Area (where Iceland belongs) and, in particular, the failure of home-country control. Foreign bank branches, which proved to be systemically critical and a menace to the host country's systemic stability, were, nevertheless, supervised by their home regulator. ${ }^{158}$ Even more damning was the fact that the identified loopholes in supervision were left unattended while the level of harmonization of national prudential regulation regimes was getting increasingly dense. Third, the uncoordinated bank rescues, and especially the Fortis case, highlighted the lack of cross-border structures for crisis management and bank resolution.

These gaps in E.U. financial supervision called for a radical rethink of regulatory structures in the European Union. In November 2008, the Commission mandated a High-Level Group, chaired by Jacques de Larosière, to make recommendations on how to strengthen European supervisory arrangements to improve investor, consumer, depositor, and taxpayer protection and rebuild trust in the financial system. The group identified big gaps in the supervision of E.U. markets, including the absence of a systemic risk oversight body. The High-Level Group recommended reforms to strengthen the supervision of the E.U. financial sector and ways to facilitate consistent implementation of harmonized rules in its final report, presented on February 25, 2009 (the de Larosière Report). ${ }^{159}$ The group recommended the establishment of pan-European supervisory structures comprising three European Supervisory Authorities (ESAs) - one for the banking sector, one for the securities sector, and one for the insurance and occupational pensions sector-to replace the corresponding Lamfalussy process committees (CEBS, CESR, CEIOPS). It also recommended the creation of a European Systemic Risk Council.

158. FSA, REgUlATORY ResPONSE, supra note 142, at 37-39; House OF LORDS, THE FutURE of EU FinanCial REgUlation and SUPERVISION: Home-Host COUNTRY SUPERVISION (2009), available at www. publications.parliament.uk/pa/ld200809/ldselect/ldeucom/106/10610.htm.

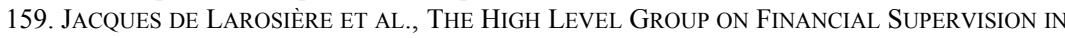
THE EU: REPORT (2009), available at http://ec.europa.eu/internal_market/finances/docs/ de_larosiere_report_en.pdf; see also IEKE VAN DEN BURG \& DANIEL DĂIANU, REPORT WITH RECOMMENDATIONS TO THE COMMISSION ON LAMFALUSSY FOLLOW-UP: FUTURE STRUCTURE OF SUPERVISION (2008), available at http://www.europarl.europa.eu/sides/getDoc.do?pubRef=//EP//NONSGML+REPORT+A6-2008-0359+0+DOC+PDF+V0//EN. 
Following the recommendations of the de Larosière Report and substantial further consultations, financial supervision in the European Union has undergone very extensive reform. The general characteristics of the E.U. reforms may be summarized as follows. First, macroprudential oversight and systemic risk monitoring have predominantly become the job of the newly established European Systemic Risk Board (ESRB). ${ }^{160}$ Second, the European Union has abolished the last remnants of the principles of minimum harmonization and mutual recognition in E.U. financial services regulation. The standard-setting competence of the new ESAs makes them the central pillars and channels of maximum harmonization through their competence to draft the new E.U. regulatory standards for financial markets and the provision of financial services with a view to establishing common E.U. rulebooks. The ESAs are also the monitors of consistent application of harmonized rules at the national level. ${ }^{161}$ Third, certain aspects of the supervision of cross-border groups have (implicitly) shifted from home country control to transnational supervisory structures comprising essentially supervisory colleges ${ }^{162}$ and the new ESAs. These changes have made the supervision of cross-border financial groups a much more collaborative effort. Fourth, until an E.U.wide bank resolution and insolvency regime is implemented with fiscal burden sharing arrangements attached to it, the resolution of cross-border institutions remains a national responsibility, notwithstanding the collab-

160. Regulation (EU) No. 1092/2010 of the European Parliament and of the Council of Twenty-four November 2010 on European Union macro-prudential oversight of the financial system and establishing a European Systemic Risk Board, OJ L 331/1, 15 December 2010. Note that this Article was completed before July 31, 2012, and thus it does not discuss the key reforms pertaining to the European Banking Union and especially the centralization of bank supervision in the Eurozone through the establishment of a Single Supervisory Mechanism operated by the European Central Bank.

161. Regulation (EU) No. 1093/2010 of the European Parliament and of the Council of Twenty-four November 2010 establishing a European Supervisory Authority (European Banking Authority), amending Decision No. 716/2009/EC and repealing Commission Decision 2009/78/EC, OJ L 331/12, 15 December 2010; Regulation (EU) No. 1094/2010 of the European Parliament and of the Council 24 November 2010 establishing a European Supervisory Authority (European Insurance and Occupational Pensions Authority), amending Decision No. 716/2009/EC and repealing Commission Decision 2009/79/EC, OJ L 331/48, 15 December 2010; Regulation (EU) No. 1095/2010 of the European Parliament and of the Council of 24 November 2010 establishing a European Supervisory Authority (European Securities and Markets Authority), amending Decision No. 716/2009/EC and repealing Commission Decision 2009/77/EC, OJ L 335/84, 15 December 2010.

162. Directive 2009/111/EC of the European Parliament and of the Council 16 September 2009 amending Directives 2006/48/EC, 2006/49/EC and 2007/64/EC as regards banks affiliated to central institutions, certain own funds items, large exposures, supervisory arrangements, and crisis management OJ L 302/97, 17 November 2009. This Directive maintains the supervisory powers of national competent authorities are not diluted, Recital 6. 
orative arrangements for crisis management and bank resolution the E.U. Commission proposes to implement.

\section{B. A Radically New Basel Accord}

\section{The Shift to Macro-prudential Regulation}

In the aftermath of the crisis, the BCBS has radically redesigned its capital adequacy standards, and it has introduced a new supervisory framework to regulate liquidity (adequacy) and a global leverage ratio. ${ }^{163}$ $\mathrm{BCBS}$ has also issued standards to improve risk management and governance in the banking sector. The main objective of the new capital measures introduced by Basel III is to resolve the chronic problem of bank under-capitalization, a widespread phenomenon during the crisis, which led to a large number of bailouts. This behavior was also a byproduct of the application of the previous Basel Capital Accords. ${ }^{164}$ Basel III aims to ensure that banks are able to withstand the type of stress experienced during the GFC, including banks' exposure to the economic cycle, bubbles, and other macroeconomic developments. The preceding Basel framework was exclusively reliant on micro-prudential regulation measures, although micro-prudential regulation sees risk as exogenous, caused by the actions of individual financial institutions, and it "neglects the systemic implications of common behaviour" of banks in the economy. The GFC has not only underscored the importance of resilient financial institutions for the stability of the system, since individual institution failure can always trigger a cascade effect due to loss of confidence, but also has highlighted the importance of guarding against endogenous risks to the system. For instance, prudent decisions to raise new funds or sell assets made by individual institutions can create negative (liquidity and fire sales) externalities with the potential to destabilize the financial system. The new Accord has both a micro-prudential focus and a macroprudential focus. Therefore, it aims to enhance bank resilience at periods of stress and address system-wide risks as well as the procyclical amplification of these risks over time. ${ }^{165}$

163. Basel Comm. On Banking Supervision, Basel III: A Global Regulatory FRAMEWORK, supra note 122.

164. See Basel Comm. on Banking Supervision, The Basel Committee's Response to THE FINANCIAL CRISIS: REPORT TO THE G20, supra note 116.

165. Philip E. Davis \& Karim Dilruba, Macroprudential Regulation-The Missing Policy Pillar (Brunell Univ. W. London Dep't Econ. \& Fin., Working Paper No. 09-30, 2009), available at http://www.brunel.ac.uk/_data/assets/pdf_file/0016/82123/0930.pdf. Macro-prudential surveillance may also help alert central banks imminent financial instability. Id. Others, however, argue that overreliance on macro-prudential regulation might lead to a neglect of market discipline that is, allegedly, a desirable byproduct of micro-prudential capital adequacy rules. See Anil Kashyap, Raghuram 
However, defining the actual role, tools, and boundaries of macroprudential policy is not as straightforward as it might sound in spite of the significance this policy has acquired in the surveillance and reinforcement of the stability of national financial systems and thus of the international financial system. ${ }^{166}$ Macro-prudential policy is a complement to micro-prudential policy, and it interacts with other types of public policy that have an impact on financial stability, such as monetary or fiscal policy_but it is no substitute for them. ${ }^{167}$ Therefore, the role of macro-prudential policy is not to manage (or dampen) aggregate demand. When it comes to safeguarding macro-economic stability, it is no substitute for monetary and fiscal policies. Macro-prudential policy may not act as a defense against inflation or macro-economic imbalances, and it merely intends to buttress the stability of the financial system by controlling the credit growth that normally leads to asset price growth, which in combination with increasing risk appetite, often driven by irrational exuberance, is a fundamental source of financial instability.

There are three defining elements of macro-prudential policy. First, its objective is to limit systemic or system-wide financial risk. Second, its analytical focus is the financial system as a whole and its interactions with the real economy. Third, the set of powers and instruments used for this purpose and their governance are, namely, prudential tools and those specifically assigned to macro-prudential authorities.

The FSB, IMF, and BIS hold that nonprudential tools are part of the macro-prudential policy toolkit only if they target, on a continuous basis, systemic risk and are part of the institutional framework used to "conduct macro-prudential policy."168 A key component of successful macroprudential policies is effective diagnosis of systemic risk buildup. ${ }^{169}$

Rajan \& Jeremy Stein, Rethinking Capital Regulation 21-23 (Mar. 2008) (unpublished manuscript), available at http://www.kc.frb.org/publicat/sympos/2008/KashyapRajanStein.08.08. 08.pdf.

166. In the Seoul G-20 Summit in November 2010, G-20 Leaders asked the FSB, IMF, and BIS for a joint report, elaborating on progress achieved in identification of best practices on macroprudential policy frameworks. In February 2011, the three organizations provided a first report defining the basic elements of macro-prudential policies and summarizing the work underway internationally and nationally to develop effective macro-prudential policies and frameworks. See FIN. Stability BD., Macroprudential Policy TOOls and Frameworks, Update to G20 Finance MiNISTERS AND CENTRAL BANK GOVERNORS (2011).

167. Id. at 2.

168. $I d$.

169. "Macroprudential polices aim to address two dimensions of system-wide risk: first, the evolution of system-wide risk over time - the 'time dimension'; and second, the distribution of risk in the financial system at a given point in time - the "cross-sectional dimension." Id. Moreover, "the key issue in the cross-sectional dimension is to reduce systemic risk concentrations, which can arise from similar exposures across financial institutions (from assets, liabilities, dependence on common services) or because of the direct balance-sheet linkages among them (e.g., counterparty risk)." $I d$. at 3. 
BCBS also intends to limit interconnectedness. According to BCBS, several of the Basel III capital requirements, which mitigate risks arising from firm-level exposures, also help to address systemic risk and interconnectedness. These include: (1) capital incentives for banks to use central counterparties for OTC derivatives; (2) higher capital requirements for trading and derivative activities, as well as complex securitizations and off-balance sheet exposures (for example, structured investment vehicles); (3) higher capital requirements for inter-financial sector exposures; and (4) the introduction of liquidity requirements that penalize excessive reliance on short-term, interbank funding to support longer dated assets.

A further consideration that has been voiced in consultations that go beyond the Basel III framework is whether a tailor-made system of protections should be extended to certain institutions that may have systemic importance. ${ }^{170}$ BCBS has developed a proposal on a methodology comprising both quantitative and qualitative indicators to assess the systemic importance of financial institutions at a global level, ${ }^{171}$ which the FSB has endorsed. ${ }^{172}$ Regulatory proposals addressing the problem of GSIFIs ${ }^{173}$ by means of a coordinated cross-border resolution regimes and contingent capital instruments.

\section{New Capital and Liquidity Regulations}

Basel III introduces higher levels of capital for banks. First, the minimum requirement for common equity, which is regarded as the best form of loss absorbing capital, will be raised from the $2 \%$ level of the previous Basel Accords, before the application of regulatory adjustments, to $4.5 \%$ of risk-weighted assets (RWAs) after the application of stricter adjustments. To this shall be added a capital conservation buffer of up to $2.5 \%$ of RWAs, which will bring the total minimum of common equity

170. Jean-Charles Rochet, Systemic Risk: Changing the Regulatory Perspective, 6 INT'L J. Cent. Banking 259, 259-76 (2010). In the Seoul G-20 Summit, held on November 12, 2010, the G-20 Leaders endorsed a requirement that SIFIs, initially in particular G-SIFIs, should have higher loss absorbency capacity to reflect the greater risks that these firms pose to the global financial system. See G20 Seoul Summit, The Seoul Summit Document 7 (2010).

171. Press Release, Basel Comm. on Banking Supervision, Measures for Global Systemically Important Banks Agreed by the Group of Governors and Heads of Supervision (June 25, 2011) (on file with author); see also Fin. StABility BD., REducing MORAL HAZARD Posed BY SYSTEMICALLY IMPORTANT FinANCIAL INSTITUTIONS-INTERIM REPORT TO G20 LEADERS 5 (2010) [hereinafter FSB, REDUCING MORAL HAZARD], available at www.financialstability board.org/publications/r_100627b.pdf.

172. Fin. Stability Bd., Progress in the Implementation OF the G20 RECOMMENDATIONS FOR STRENGTHENING FINANCIAL STABILITY - REPORT OF THE FINANCIAL STABILITY BOARD TO G20 FINANCE MinisTERS AND CENTRAL BANK GOVERNORS (2011).

173. See FSB, REDUCING MoRAl HAZARD, supra note 171. 
in bank capital to $7 \%$ of RWAs by 2019 , when all reforms will have been implemented. The Tier 1 capital requirement, which includes common equity and other qualifying financial instruments, selected on the basis of strict criteria, that give them loss absorption capacity equal to equity, will increase from $4 \%$ to $6 \%$ (before factoring in the conservation buffer). This higher level of capital is coupled with a stricter definition of common equity and an increase in capital requirements for trading activities, counterparty credit risk and capital markets-related activities, for which a higher capital charge shall apply. Furthermore, Basel III gives supervisors the discretion to require additional capital buffers during periods of excess credit growth in order to contain bubbles (countercyclical buffer). In addition, competent supervisors may require systemically important banks to increase their loss absorbency capacity.

Incontrollable procyclical leverage was partly responsible for the extreme fragility of the global financial system and the extent and depth of the GFC. Basel III is trying to remedy this situation through the welcome introduction of restrictions on banks' leverage. Unlike the Basel III regulatory capital framework, which, like its predecessor, remains riskbased, the new Basel III leverage ratio is a simple number which captures on- and off-balance sheet exposures and net derivatives positions and is not related to any risk adjustment calculations. Namely, the nonrisk-based leverage ratio is meant to serve both as a safety valve and a means to contain regulatory arbitrage, which increases leverage through off-balance sheet assets transformation, serving as a backstop to the riskbased capital requirement. ${ }^{174}$

The GFC started as a credit crunch, which meant that wholesale lending markets became very illiquid, forcing the failure of financial institutions like Northern Rock, which were highly dependent on shortterm funding. The continuing liquidity hoarding also forced all banks to become dependent on central bank liquidity schemes for their short-term funding. Lack of any regulatory standards that would require banks to hold a minimum of liquid assets as liquidity reserves came to be regarded as one of the most important loopholes of the Basel capital adequacy regimes. In response, Basel III has introduced minimum liquidity standards to make banks more resilient to potential short-term funding disruptions. The liquidity coverage ratio (LCR) will require banks to have sufficient high-quality liquid assets to withstand a stressed funding scenario that is

174. "The use of a supplementary leverage ratio will help contain the build-up of excessive leverage in the system. It will also serve as an additional safeguard against attempts to 'game' the risk-based requirements and will help address model risk." BASEL COMM. ON BANKING

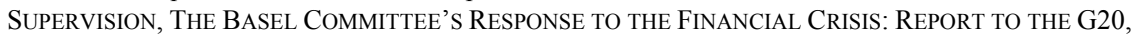
supra note 116 , at 5 . 
specified by supervisors over a period of thirty calendar days. Basel III liquidity standards also address the longer-term structural liquidity mismatches normally encountered in bank balance sheets, which, in part, are due to the business of banking that mainly consists of transforming shortterm liabilities (deposits) to long-term assets (loans). Thus, the net stable funding ratio (NSFR) will serve as a measure to address longer-term (structural) liquidity mismatches. Banks will have to show that they can provide a sustainable maturity structure of assets and liabilities over a period of one year. NSFR covers the entire balance sheet and its clear objective is to incentivize banks to use stable sources of funding.

\section{AN INSTITUTIONAL BIG BANG FOR GLOBAL FINANCE}

Part V sets out this Article's proposal for the reform of global financial governance. It explains the rationale for a radical reform of global financial governance and outlines the main tenets and objectives of such a new governance structure for global finance.

\section{A. Rationale}

The aforementioned regulatory reforms might prove of variable effectiveness but still are doubtlessly a marked improvement over previous arrangements in a number of areas, including OTC derivatives trading, financial institution resilience, and national and regional systemic risk monitoring. However, said reforms provide limited comfort when it comes to cross-border supervision of large systemically important crossborder financial institutions, management of emerging risks, due to unpredictable combinations or correlations of forces unleashed or shaped by financial innovation with other market and real economy forces, and resolution of cross-border financial groups.

A closer examination of recent reforms for the supervision of systemic risks in the European Union and the United States would reveal two awkward truths. First, their mandate is inevitably limited to the U.S. and E.U. borders. Accordingly, it is still open to question which authority, if any, is responsible for the protection of global systemic stability. Second, although both the U.S. and E.U. regimes will be geared toward global macro-prudential developments, from the movement of interest rates in other countries or regions to sovereign debt, they do not possess the tools to properly monitor the biggest channel of credit intermediation in the world: the shadow-banking sector. ${ }^{175}$ They also lack any power of intervention in those markets. These shortcomings could undermine,

175. The risks of shadow banking were analytically are discussed in FSB, SHADOw BANKING, supra note 4. 
through regulatory arbitrage, current regulatory efforts to create a safer financial system in very effective and invisible ways. For instance, it gives ample opportunity for regulated entities to evade the stricter leverage and liquidity requirements imposed by Basel III. ${ }^{176}$

Despite recent reforms, many gaps remain in the supervision of large financial institutions and groups operating on a global basis. These fractures would almost certainly lead to three insurmountable problems that would make the operation of G-SIFIs a continuous source of moral hazard, notwithstanding the important new regulations that are underway to limit it. First, while the cross-border operation of financial institutions can give rise to cross-border contagion leading to a generalized financial crisis, ${ }^{177}$ the incentives of the home supervisor to prevent this outcome could possibly be weak. As the collapse of the Icelandic banks has shown, home-country supervisors are certain to face weak incentives to intervene promptly, when the main asset or deposit base of the institution in trouble is in another jurisdiction. Supervisory colleges might make exchanges of information smoother, facilitating supervision, but they are unlikely to prove an effective crisis management and resolution mechanism. Because colleges do not have power of intervention, especially as it relates to the Prompt Corrective Action (PCA) and resolution, it is unlikely that home supervisors will be forced to act when they stand to lose reputation and money (from the deposit insurance fund, the resolution fund, or due to a public bailout), in order to protect or rescue depositors or other creditors of the financial institution who are located in other jurisdictions. It should be noted that this was widespread behavior during the GFC and it is not an assumption based on a theoretical model. ${ }^{178}$ In addition, in the absence of a unitary supervision regime, regulatory coordination between home and host authorities is bound to be slow and in-

176. Id. at 8 ("If parts of the shadow banking system are able to operate without internalising the true cost of its risks and thus gain a funding advantage relative to banks where regulation aims to achieve such an internalisation, this is likely to create opportunities for arbitrage that might undermine bank regulation and lead to a build-up of additional leverage and risks in the system. Moreover, banks themselves may use shadow banking entities to increase leverage and find ways to circumvent their regulatory capital or liquidity requirements.").

177. For a good analysis of contagion channels opened by the cross-border operations of financial institutions, see Hans Degryse et al., The Impact of Cross-Border Exposures on Financial Contagion, in Financial Regulation at the Crossroads, Implications for Supervision, Institutional Design AND TRADE 26-32 (Panagiotis Delimatsis \& Nils Herger eds., 2011).

178. "During the current crisis one of the most commonly observed phenomena was discrimination against host country/foreign borrower." See U.N. COMM'N ON REFORMS OF INT'L MONETARY $\&$ FIN. SYS., REPORT OF THE COMMISSION OF EXPERTS OF THE PRESIDENT OF THE UNITED NATIONS GENERAL ASSEMBLY ON REFORMS OF THE INTERNATIONAL MONETARY AND FINANCIAL SYSTEM 56 (2009) [hereinafter, U.N. EXPERTS' REPORT]. In addition, in the tightly interconnected world of modern market economies regulatory forbearance in the home country can have a debilitating impact on economic growth in the host country. Id. 
coherent due to their conflicting objectives. ${ }^{179}$ Second, inconsistent implementation and application of the new Basel III rules would more or less mean that different regulatory arbitrage channels are bound to open, undermining the effectiveness of reforms. ${ }^{180}$ Third, the multitude of national regulators that shall be involved in the calculation and application of the countercyclical buffer to G-SIFIs will prove to be an obstacle to its effective and consistent application to these institutions. ${ }^{181}$

Moreover, there is no crisis if one big group of stakeholders in financial markets do not lose their rational calm and become irrationally risk averse and panic sellers, regardless of whether they are sophisticated investors and creditors or the general public. At the same time, widespread herding is an ever-present characteristic in all bubbles. ${ }^{182}$ There is little doubt that this sort of herding is triggered or boosted by sociopsychological reasons, whether irrational exuberance or just competition for the highest payment package among peer groups. But it may not be modeled with any degree of accuracy. Herding behavior is ever-present both in periods of growth and decline. In the latter case, the momentum game goes into reverse and panicking investors start selling. ${ }^{183}$

The need for a global public regulatory policy and risk knowledge body is even bigger in light of the marked and continuous criticism directed at CRAs who are the private sector's financial risk knowledge processors and assessors in the global marketplace. Apart from the multitude of other flaws, CRA ratings also seem to be unpardonably procyclical or tend to de facto dictate international public policy. In the context of the ongoing sovereign debt crisis, CRAs have plausibly been

179. See CARMINE LAMANDA ET AL., UNICREDIT Group Forum ON FinANCIAL CROSSBORdER Groups, Discussion PAPER: CROSS-BORdER BANKING IN EUROPE: WHAT REGULATION AND SUPERVISION? 8 (2009).

During the financial crisis the situation of the banking system was assessed mainly at the national level and remedial action was also defined at country level in the European Union (EU). This may have prevented the efficient use of private resources and may have increased the overall cost to public finances. Coordination and cooperation between national supervisors have proved ineffective in the crisis management of multinational financial institutions where speediness was required (Fortis).

Id.

180. See Capital and Liquidity Standards: Hearing Before the H. Comm. on Fin. Servs., 112th Cong. (2011) (testimony of Daniel K. Tarullo, Bd. of Governors, Fed. Reserve Sys.), available at www.federalreserve.gov/newsevents/testimony/tarullo20110616a.htm.

181. For a discussion of this issue and an insightful discussion of the several fractures presented by the emerging financial architecture, see Barry Eichengreen, Keynote Address at the Annual Research Conference of the Bank of Korea 2-4 (May 26, 2011), available at http://emlab.berkeley.edu/ eichengr/Reforming_Intl_Arch_2011_Ed.pdf.

182. Charles P. Kindleberger \& Rober Z. Alliber, Manias, Panics, and Crashes: A HISTORY OF FINANCIAL CRISIS (5th ed. 2005).

183. For a discussion of how this can translate into escalating volumes of short sales, see Avgouleas, New Framework, supra note 119, at 376-425. 
accused of creating a string of self-fulfilling prophecies with their aggressive downgrading of E.U. sovereign borrowers. ${ }^{184}$

Finally, the aforementioned U.S. and E.U. reforms in the field of bank resolution as well $\mathrm{IMF}^{185}$ and FSB proposals constitute a significant step forward, especially with respect to the orderly resolution of SIFIs with minimum involvement of public funding to minimize moral hazard. Yet another big problem remains that of the cross-border resolution of financial groups. There is nothing in the present reforms that provides a convincing answer to this problem, which is further intensified by the lack of a single regime for the resolution of cross-border financial groups on a unitary basis instead of holding separate proceedings for each group entity with a different legal personality.

\section{B. The Proposed Governance Model}

The global financial governance model I outline below constitutes a global regulatory "big bang," but it is not a new Bretton Woods, nor is it the answer to other global economic challenges, such as trade imbalances. For a number of years, clear lines of responsibility and expertise have developed in the various corners of global financial governance. If one examines them carefully and puts the fragmented lines together, they automatically provide a rough guide to what is the right path to reform. The governance model presented here has also considered similar efforts to chart a global financial governance model originating from other academic works, yet it is sharply different from and farther reaching than previous proposals. ${ }^{186}$ Finally, it is based on, as it ought to be, knowledge we now have about: (1) the workings of global finance; (2) the causes of the GFC and the contours of the financial revolution; and (3) the other challenges modern markets and economies face such as the widespread moral hazard too-big-to-fail institutions give rise to and the development objective. If this can be achieved, then the resulting governance framework for global finance would only require minimal expenditure and politically manageable tinkering with existing international arrangements.

184. See Dirk Kurbjuweit, Essay: Die Politik im Griff der Finanzmärkte, 22 DER SPIEGEL (2011); OECD Joins Criticism of Credit Rating Agencies, EUbUSINESS.COM (July 7, 2011), www.eubusiness.com/news-eu/oecd-eurozone-debt.b5x/.

185. InT'L MONETARy Fund, Resolution of Cross-Border Banks-A Proposed FRAMEWORK FOR ENHANCED COORDINATION (2010).

186. Among the most comprehensive ones are the U.N. Commission of Experts' proposal for the establishment of a Global Economic Coordination Council (see U.N. EXPERTS' REPORT, supra note 178, at 87) and John Eatwell's for the establishment of a global prudential (systemic risk) authority, suggested in many works - the most recent of which is KERN ALEXANDER, RAHUL DHUMALE \& John EATWELL, GLOBAL GovernanCE OF FinANCIAL SySTEMS: THE INTERNATIONAL REGULATION OF SYSTEMIC RISK (2006). 
1. General Principles: The Importance of Shared Values

The existence of a set of commonly accepted shared values is of cardinal importance for both the effectiveness and legitimacy of a multilayered governance structure. ${ }^{187}$ The same applies to the nexus of relationships between the proposed supranational governance system and member states and other constituents, such as the financial institutions overseen by the scheme. Therefore, the statutes of the bodies involved in the proposed system would have to be amended, making all four organizations accountable, for their regulatory mandate to a Treaty-established governing council of twenty-five representatives. This council would comprise of the G-20 members (Ministers or Heads of State), the European Union, as an organization separate from its members, the United Nations, as an organization separate from its members, the World Bank, and the three most important national economies from those that are not represented in the G-20. The governing council could be convened every six months or whenever important matters have to be discussed. In addition, the head of the governing council, a post held by members of the governing council on a rotating basis, would have to file an annual report about the work of the new authorities before the U.N. General Assembly. In addition, key nongovernmental organizations (NGOs) should be sitting on the board of the financial policy authority and even be given voting rights when debating issues within the NGOs' areas of expertise.

Within the proposed structure, the four authorities would be of equal status and they would be mandated to cooperate in full, especially when it comes to exchange of information, initiation of joint regulatory action, or processing and evaluating data. The important decisions of the suggested system of global financial governance would be jointly decided by the heads of the four authorities. However, each authority would have the decisive vote in its respective governance field: systemic risk supervision, micro-prudential supervision, regulation production and resolution. Any critical disagreements would be referred to the chairman of the governing council or the council plenary, but this right would cover only planning decisions and not instances where speedy action would be required, such as imposition of sanctions, prevention of activities that threaten systemic stability, or initiation of resolution proceedings. Naturally, in the process more detailed rules would have to be instilled to allow the system to take effective and responsible action without fears of abuse. Thus, the system would eventually develop its own set of global

187. Thomas Cottier, Multilayered Governance, Pluralism, and Moral Conflict, 16(2) IND. J. GLOBAL LEGAL STUD. 647 (2009); Weber, supra note 134, at 683-704. 
administrative law rules. These arrangements would provide clarity in the relationship between the different authorities of the proposed scheme.

The scheme could not come into existence unless G-20 countries, the rest of the E.U. members, and other key economies sign an international treaty establishing a supranational governance structure for global finance. Thus, it would become mandatory for participating jurisdictions. Beyond participating members the scheme would be voluntary. Unsurprisingly, if all G-20 economies and the rest of the European Union subscribe to the new governance scheme, following the signing of an international agreement, it would be impossible for the rest of the world not to join. Apart from the quality and credibility mark lent to institutions supervised under the scheme, the new governance system would also provide a further advantage. It is suggested that the scheme should provide to institutions falling under its remit full freedom of establishment in foreign jurisdictions and freedom to offer services on a cross-border basis, subject to local rules of conduct. Namely, it is proposed to give institutions governed by the scheme a "single passport" facility similar to that granted by E.U. member states to any financial institution licensed in the European Union.

The scheme would only be able to provide this facility if WTO signatories agreed to a modification in the GATS rendering the "prudential regulation carve out" inapplicable for financial institutions governed by the proposed governance scheme. This should not prove an insurmountable problem, because, with the implementation of the suggested scheme, authorities would be taking important steps to safeguard systemic stability. This further liberalization of global trade in financial services should be able to return to the WTO negotiations agenda. The departure point for holding the regulatory bodies of the new structure accountable would be their compliance not only with their charters but also with a set of general principles that should govern their actions. Several attempts have been made to first identify those principles and then define them, also with reference to the general principles governing ${ }^{188}$ the operation of the leading international finance TRNs such as IOSCO. ${ }^{189}$ In this context, I view three principles as beyond dispute. These are the need to:

(1) safeguard the global public good of financial stability;

(2) protect the robustness of financial infrastructure; and

188. Luis Garricano \& Rosa Lastra, Towards a New Architecture, 3 J. INT’L ECON. L. 597, 606-20 (2010); Weber, supra note 134, at 693-94.

189. See InT'L ORg. OF Sec. Comm'ns, Objectives And Principles of SeCurities REGULATION (2010), available at www.iosco.org/library/pubdocs/pdf/IOSCOPD323.pdf. 
(3) safeguard the integrity of global markets and protect investors and consumers of financial services from abusive practices and products that may be unsuitable to their risk profile.

I would suggest adding a fourth principle to this list, even though it may only be seen as a supplement to the principle of financial stability. All actions of the new system should be cognizant of their impact on the ability of open and competitive financial markets to foster economic growth, when the objective of financial stability is not compromised.

However general and abstract this principle might sound at this stage, it is a substantial leap forward. After all, it is not meant to provide the foundation for litigation or judicial review but to signal to the proposed regulatory bodies and the rest of the world the importance of two major issues that were largely underestimated in the past: that, first, financial crises and regulators' actions to prevent or contain them and, second, open and competitive markets, have significant impact on economic development, and this causal link may no longer be ignored. ${ }^{190}$ Thus, the importance of the fourth principle should not be underestimated in terms of the direction that it would provide to the new governance structures and the regulations they would produce.

I have explained elsewhere the possibility of creating very low-risk weights under the Basel framework for certain classes of microcredit used to pursue an economic activity or buy a productive asset or for those that have an embedded borrower monitoring mechanism as group loans do. ${ }^{191}$ Giving these loans a preferential treatment in terms of capital regulations would provide a significant impetus to the industry without compromising financial stability. ${ }^{192}$ The repayment rate of such loans sometimes touches $100 \%$, but it is very hard for this fact to be clearly observed in the absence of written records or credit registries in the countries where such loans are mostly supplied. The suggested financial policy regulator could thus undertake its own independent examination of repayment rates for such loans, using a variety of formal and informal sources. Once satisfied with the outcome, it could produce capital regulations that reflect the reality of low default ratios for group microfinance loans. The same regulatory incentives (low capital requirements) route could be followed with debt to equity exchange schemes for loans to de-

190. This observation only means that the principle could not be litigated. It is not to say that domestic regulatory systems should not incorporate this principle in more binding terms, given the importance of law in fostering development. See Ross Cranston, How Law WorKS (2006); DOUglas ARnER, FinANCIAL Stability, ECONOMIC Growth AND tHE ROLE OF LAW (2007).

191. See Emilios Avgouleas, Access to Finance, Microfinance, and International Banking Regulation: A New Approach to Development, 4 MANCHESTER J. INT'L ECON. L. 3, 3-51 (2007).

192. See Emilios Avgouleas, International Financial Regulation, Access to Finance, Systemic Stability, and Development, 2008 LAWASIA J. 62-76 (2008). 
veloping countries that go beyond exchanges between creditor and debtor nations ${ }^{193}$ and extend to private institutions, once certainty is established, following relevant studies, that financial stability is safeguarded.

The existence of a set of commonly accepted values for the effectiveness and legitimacy of a multi-layered governance system like the one proposed here may not be overstressed. It is the foundation of any multi-layered system of governance and the material that holds it together reinforcing its legitimacy. ${ }^{194}$ In addition, including the development objective in the new governance structure, notwithstanding the supremacy of the financial stability objective, would signal a marked reorientation of global finance. This is of cardinal importance because it would emphasize to global finance operators and to people in developing nations the possibilities global finance holds in resolving several development issues. This, in turn, is a very good way to create a community of interests between the two and thus broaden the legitimacy of the proposed governance system. Binding global technocratic institutions, like the ones proposed here, to a set of "shared values" that would promote global welfare objectives is, arguably, an excellent way to enhance their legitimacy.

\section{The Macro-prudential Supervisor}

The first pillar of the proposed governance system, the global systemic risk (macro- prudential) supervisor that would monitor both macroeconomic developments and the state of the global financial system, seen as encompassing national, regional, and international financial systems and the shadow-banking sector, should comprise a revamped IMF. ${ }^{195}$ Assigning this duty, by means of an international treaty, to a revamped IMF makes good sense, given also the IMF's monitoring role with respect to national balance of payments and sovereign indebtedness. In fact, the entanglement of financial sector stability and solvency with sovereign indebtedness and vice versa means that only a revamped IMF could effectively discharge the duties of a global macro-prudential supervisor.

In addition, the IMF should be given the tools to monitor closely the shadow-banking sector, in order to close the current supervisory dis-

193. For a discussion of these schemes, see Ross Buckley, Debt-for-Development Exchanges: An Innovative Response to the Global Financial Crisis, 32 U. NEW S. WALES L.J. 620 (2009).

194. As Cottier has perceptively noted, "[m]ultilayered governance thus relies upon a common and shared body of underlying constitutional values and legal principles ...." Cottier, supra note 187 , at 657.

195. Rosa Lastra \& Luis Garricano, IMF and the Architecture for Financial Stability: Seven Principles, 13 J. INT'L ECON. L. 597, 597-621 (2010). 
continuities, especially as they relate to systemic risk data collection and processing. A possible way to do this would be to require all shadow banks and hedge funds to register with the IMF and file regular reports with it. The scheme should be properly calibrated in terms of asset thresholds to capture only important shadow-banking vehicles. Thus, it should provide for de minimis exemptions to avoid registration of small funds. In the unlikely event that it is proven that sovereign wealth funds are a significant source of global market instability, the IMF should be given the tools to monitor closely the shadow-banking sector in order to close the current supervisory discontinuities, especially systemic risk data collection and processing.

Finally, like the ESRB, the IMF should be entitled to recommend to national regulators, or the global micro-prudential supervisor that is suggested here, a course of defensive action against an emerging systemic threat. It should also be considered whether, in the context of the same treaty, it would be feasible to give the IMF the power that Dodd-Frank has already given to FSOC, and the ESRB can exercise indirectly, to require financial institutions to act upon emerging systemic risks that in its judgment give rise to significant concern that justifies adoption of remedial action. In both cases, the global macro-prudential supervisor may only be involved where the risk concerned constitutes a threat to more than one jurisdiction or has the possibility of creating a cross-border crisis.

\section{The Micro-prudential Supervisor}

Political objections and realities notwithstanding, the only effective solution to the regulation of G-SIFIs is to subject international financial institutions with a strong cross-border asset or liabilities base $(50 \%$ and higher over total assets) to the direct supervision of a global microprudential authority ${ }^{196}$ to minimize the scope for regulatory arbitrage. In the same mode, a global micro-prudential authority supervising G-SIFIs on a consolidated and individualized basis is the only way to apply uniformly and effectively the countercyclical buffer provided in Basel III. As said earlier, the role of the micro-prudential supervisor could gradually evolve into a full-fledged global markets regulator, which could eventually be asked to expand its remit and exercise oversight over megaexchanges and wholesale derivatives markets. Thus, this duty should be assigned to a reconstituted FSB, where all national banking and capital markets supervisors are already represented.

196. For similar views, see Pan, supra note 86 , at 243-84. 
The micro-prudential supervisor of G-SIFIs would monitor compliance with the globally accepted standards, such as the Basel III framework. The micro-prudential supervisor could exercise direct oversight over G-SIFIs, whether they are banks or other financial institutions, such as insurance companies, with a large cross-border asset or liabilities base. Its remit could gradually extend to cover certain wholesale segments of global derivatives and securities markets, ${ }^{197}$ resolving the problem of regulation of mega-exchanges. It is suggested that this role should be assigned to a reconstituted and expanded FSB, where all G-20 banking and capital markets regulators are already represented. The Bank of International Settlements (BIS), minus its research division, would have to merge with the FSB. Accordingly, the new micro-prudential supervisor would essentially operate from existing BIS premises in Basel, ensuring its neutrality.

The global micro-prudential authority would be entitled to ask for the assistance of the home country supervisor, which is, in any case, responsible for monitoring compliance with national rules of conduct. Such an arrangement would eliminate scope for confusion or lax supervision and weaken home country opposition to the suggested supervisory scheme. In fact, of all the parts of the proposed system of governance, this is probably the most likely to be fiercely opposed. Strong national interest dictates that each country, which serves as the home jurisdiction of a big bank or other important financial institution, wishes to be the principal regulator of this institution. This is so, first, for reasons of national economic interest, including job preservation and credit growth in the national markets, and, second, for reasons of prestige and influence in global economic affairs. Yet the logic of the proposal is too strong to be dismissed out of hand. It eliminates the scope for regulatory forbearance and provides a framework for consistent application of the new Basel III rules, which, apart from regulating capital, extend to the key prudential areas of leverage and liquidity regulation.

Obviously, if there is a possibility for this part of the proposal to ever come to fruition, the issue of loss of sovereignty must be managed or contained as much as possible. Therefore, when the micro-prudential authority would have to take enforcement against a G-SIFI, it would need to act as a college-borrowing certain elements from the operation of the new E.U. supervisory authorities, allowing key national regulators to have a say and making it a truly multilayered governance structure. Also, strong accountability mechanisms would have to be established. If

197. Cf. Donald C. Langevoort, Global Securities Regulation After the Financial Crisis, $13 \mathrm{~J}$. INT’L ECON. L. 799, 799-815 (2010). 
the finance minister of the home country is not a member of the new system's governing council, then it should be invited to attend proceedings, help with supervision, and influence decisions, although it is the global body that would ultimately make the key supervisory decisions.

\section{Global Financial Policy, Regulation, and Risk Knowledge Authority}

The third pillar of the proposed governance structure is a global financial policy body that would oversee the TRNs, including the BCBS and IOSCO, under arrangements that should be more binding than those underpinning the FSB, which currently performs this role. Suggested arrangements would not obliterate the importance of the BCBS and of other TRNs and their value as importers of private-sector knowledge and interlocutors with the private sector. This approach would make the proposed scheme a truly multi-layered and hierarchical governance structure.

This third pillar should comprise the OECD and the research division of BIS and should be occupied with the task of production of new regulation and examination of emerging risks, especially by means of various financial innovations. The new body could be called the Global Financial Policy, Regulation, and Knowledge Organization and should be the directing mind of international financial regulation. The fourth pillar should comprise a newly established Global Resolution Authority, which should deal with the resolution of big cross-border financial groups on the basis of a single resolution and insolvency model.

TRN standards would have to pass a public interest test set by the financial policy body, which would primarily focus on financial stability and the ways the draft standard serves the other general principles of the proposed governance system. Once endorsed, the standards would become binding, automatically or through mandatory implementation legislation, to all jurisdictions that have opted into the proposed scheme and signed the treaty.

The rulemaking committees of the International Swaps and Derivatives Association (ISDA), the standard-setting committee of the International Accounting Standards Board (IASB), and other important privatesector rulemaking bodies would also come under the umbrella of the financial policy regulator, and their standards would have to be endorsed by the regulator, provided that the standards met a public interest and financial stability test. This reform would secure coherence in standard setting and rulemaking in the field of international finance, eliminating the scope for rule conflict or uncertainty. The same body should play the role of global risk knowledge bank and manager. I have explained elsewhere the high costs of lack of knowledge and understanding of the me- 
chanics and potential risks of innovative financial instruments and techniques and their interaction with global economic developments, such as market liberalization. ${ }^{198}$ Neither the risks nor the potential benefits of the financial revolution can be properly managed in the absence of painstaking research and even testing innovative financial instruments and techniques in real (or stimulated) market conditions that would allow the global investment community to understand them properly and in their true dimensions.

\section{A Global Resolution Authority}

The fourth pillar of the proposed system of governance should be a global resolution authority operating a single resolution model for GSIFIs on a group basis. Its resolution operations should either be supported by burden sharing arrangements between member countries, probably using assets to GDP ratios as a basis for contributions, ${ }^{199}$ or by a global resolution fund financed by levying a global tax on G-SIFIs. The best way to calculate such a levy would be on the basis of assessment of institution riskiness using a risk matrix developed jointly with the proposed financial policy authority and TRNs, such as the BCBS, that would work under its umbrella. Calibrating a levy on G-SIFIs in this manner could satisfy both the objective of financing resolution and curbing excessive risk-taking. ${ }^{200}$

The establishment of a global resolution authority exclusively tasked with carrying out the resolution of G-SIFIs covered by the scheme would be expected to address the issues of impartiality and mistrust that all cross-border resolutions are bound to face due to the multitude of conflicting interests among creditor, shareholder, employee, and other stakeholder groups as well protection of the national interest. It would also remedy the continuous absence of special resolution regimes dealing with SIFIs in several G-20 countries, which obliterates the intended effect of such regimes, namely the reduction of moral hazard associated with "too-big-to-fail" institutions. ${ }^{201}$

198. See AvGOULEAS, supra note 3, at chs. 2-3.

199. For this model and other forms of calculating burden-sharing for bank bailouts, see Charles Goodhart \& Dirk Schoenmaker, Fiscal Burden Sharing in Cross-Border Banking Crises, 5 INT'L J. CENT. BANKING 141, 141-65 (2009).

200. Financial taxes can have three main objectives: (1) to limit excessive risk-taking; (2) to provide an insurance or resolution fund for systemically important institutions; and (3) to help pay for global public goods. Kern Alexander, International Regulatory Reform and Financial Taxes, 13 J. INT'L ECON. L. 893, 894 (2010).

201. A 2011 BCBS survey has found that the level of national implementation of Special Resolution Regimes is very low, the cross-border dimension has largely been neglected, and the issue of cross-border group resolution has been ignored. This is what the BCBS Press Release states in the customary diplomatic language of international bodies: 
The global resolution authority could only operate effectively if participating countries and institutions accepted its power of intervention and attendant modifications of their domestic laws that would be required for the global resolution authority to operate a single resolution and insolvency law for G-SIFIs. Country members of the scheme could create a special statute that would exclusively apply (lex specialis) to the resolution of SIFIs. ${ }^{202}$ Moreover, all financial institutions supervised by the proposed scheme would have to amend their statutes to incorporate the changes necessitated by the single model operated by the global resolution authority in order to minimize shareholder and creditor litigation.

\section{CONCLUSION}

Financial globalization coupled with a host of financial innovations led the world to the brink of collapse during the ongoing crisis and has pushed millions of the world's least protected citizens to experience the consequences of a deep global recession in the form of job losses and rising economic hardship. As a result, the entire project of financial globalization is in peril, because it is impossible to sustain the current environment of open markets if another crisis of a similar magnitude as the last one occurs. In terms of global economic development, this is the worst time possible to return to a closed markets system. World requirements for credit and investment to finance development, sustainability, and increased food production needs are on the rise. ${ }^{203}$ These additional funds can only come from free and open global financial markets, notwithstanding the need, in certain cases, for very short-term capital controls in order to curb speculative capital flows.

For all their excesses and sometimes even outright criminal behavior, financial markets are one of the biggest stimulators of economic growth in the modern world, and they also have a serious impact on pov-

Some jurisdictions continue to lack these and other important legal powers set out in the Basel Committee's 2010 recommendations or continue to rely on general corporate insolvency procedures. Such procedures are too slow, too costly and come too late to resolve a failing bank. ... Further work is required on cross-border resolution as complications continue to arise from discrepancies among national regimes. ... National authorities appear to be at different stages of developing recovery and resolution plans for systemically important financial institutions. In view of the importance of these plans for systemic stability, national authorities will need to move forward quickly in this area.

BASEl COMM. ON BANKING SuPERVISION, RESOLUTION POLICIES AND FrAMEWORKS-PROgRess SO FAR (2011), available at www.bis.org/publ/bcbs200.htm.

202. An outline of a single insolvency model for G-SIFIs and cross-border financial groups has been given in Emilios Avgouleas et al., supra note 150.

203. Emma Rolwey, World Needs $\$ 100$ Trillion More Credit, Says World Economic Forum, THE TELEGRAPH (Jan. 19, 2011), www.telegraph.co.uk/finance/financetopics/davos/8267768/ World-needs-100-trillion-more-credit-says-World-Economic-Forum.html. 
[Vol. 36:321

erty reduction. ${ }^{204}$ The multitude of the complex challenges financial globalization creates may not be resolved without solid and effective supranational regulatory structures governing global finance. This Article constitutes a comprehensive first attempt to provide such a model.

The model of governance proposed in this Article as the template for an institutional "big bang" for global finance has the potential to prove a much better guardian of the global public good of systemic stability than national or regional regulators and the existing TRNs. In addition, the governance structure that is proposed here is based on a set of shared values (in the form of general principles and sub-principles of governance), which could not only secure its coherence but are also much more cognizant of an additional (to financial stability) global public good: sustainable economic development! 